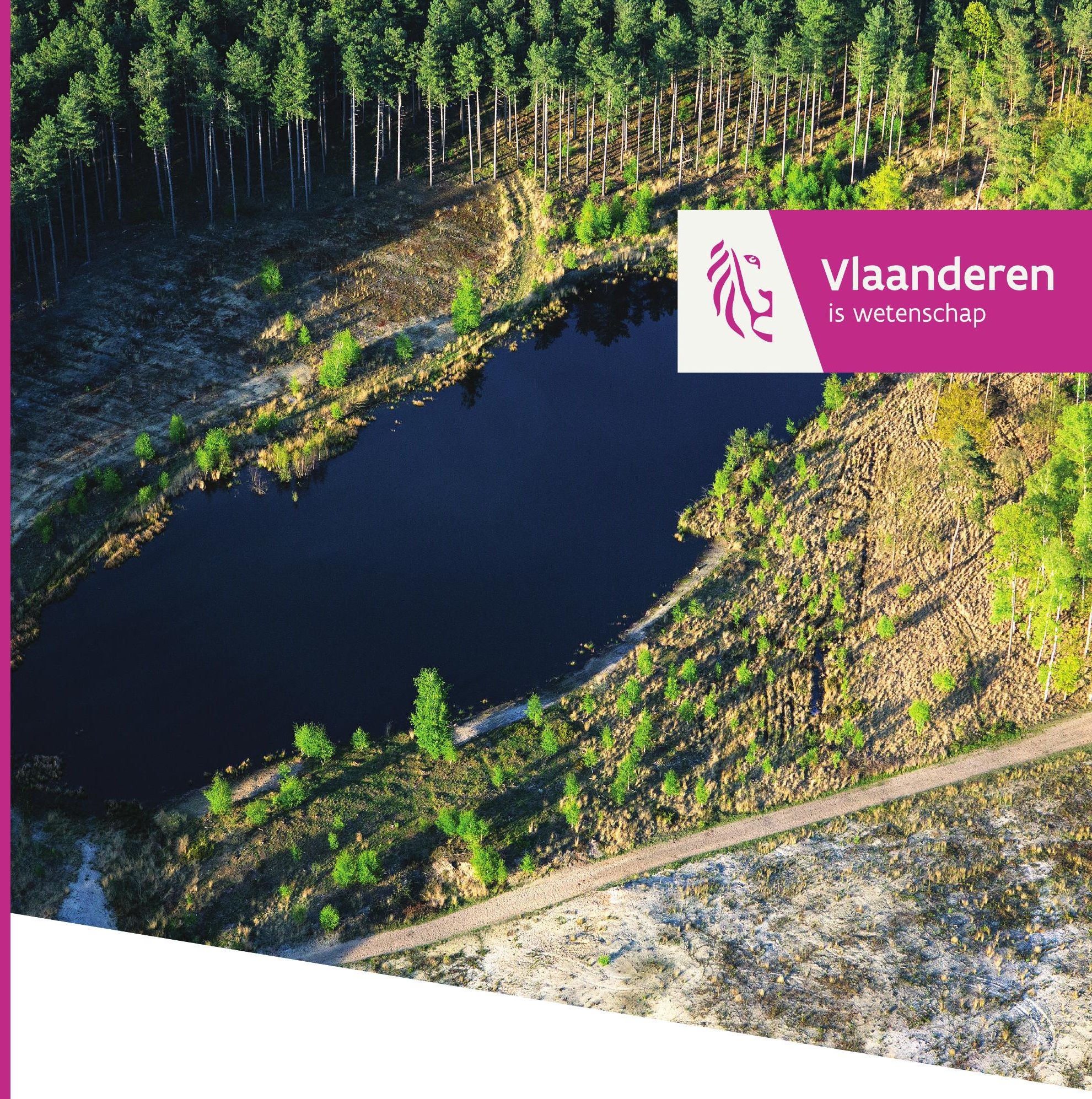

\title{
Opvolging van de reewildpopulatie in de Merodebossen
}

Frank Huysentruyt, Jan Vercammen, Axel Neukermans en Jim Casaer

INSTITUUT 


\section{Auteurs:}

Frank Huysentruyt, Jan Vercammen, Axel Neukermans en Jim Casaer

Instituut voor Natuur- en Bosonderzoek

Het Instituut voor Natuur- en Bosonderzoek (INBO) is het Vlaams onderzoeks- en kenniscentrum voor natuur en het duurzame beheer en gebruik ervan. Het INBO verricht onderzoek en levert kennis aan al wie het beleid voorbereidt, uitvoert of erin geïnteresseerd is.

\section{Vestiging:}

INBO Geraardsbergen

Gaverstraat 4, 9500 Geraardsbergen

www.inbo.be

e-mail:

frank.huysentruyt@inbo.be

\section{Wijze van citeren:}

Huysentruyt F., Vercammen J., Neukermans A., Casaer J.(2016). Opvolging van de reewildpopulatie in de Merodebossen. Rapporten van het Instituut voor Natuur- en Bosonderzoek 2016 (dx.doi.org/10.21436/inbor.11376238). Instituut voor Natuur- en Bosonderzoek, Brussel.

dx.doi.org/10.21436/inbor.11376238

D/2016/3241/298

ISSN: 1782-9054

\section{Verantwoordelijke uitgever:}

Maurice Hoffmann

\section{Druk:}

Managementondersteunende Diensten van de Vlaamse overheid

\section{Foto cover:}

(c) Wouter Pattyn | www.wouterpattyn.com 


\section{Vlaanderen}

is wetenschap

\section{Opvolging van de reewildpopulatie in de Merodebossen}

Frank Huysentruyt, Jan Vercammen, Axel Neukermans en Jim Casaer

dx.doi.org/10.21436/inbor.11376238

D/2016/3241/298 


\section{Dankwoord}

In eerste instantie willen we hier natuurlijk alle vrijwilligers bedanken voor de vele uren die zij spendeerden aan het afstappen van de trajecten en het geduldig observeren, tellen en noteren van alle gegevens. Dergelijke monitoringprojecten kunnen enkel bestaan bij gratie van een grote hoeveelheid gegevens en die vergen een grote tijdsinvestering. Het spreekt voor zich dat dit niet mogelijk is zonder de hulp van vele vrijwilligers.

Ook de verschillende beherende organisaties en overheden op het terrein verdienen een woord van dank voor hun jarenlange inzet en medewerking aan dit project. We denken hierbij aan de bevoegde mensen bij het Agentschap voor Natuur en Bos, de Provincie Antwerpen, Natuurpunt vzw en aan alle deelnemende jagers.

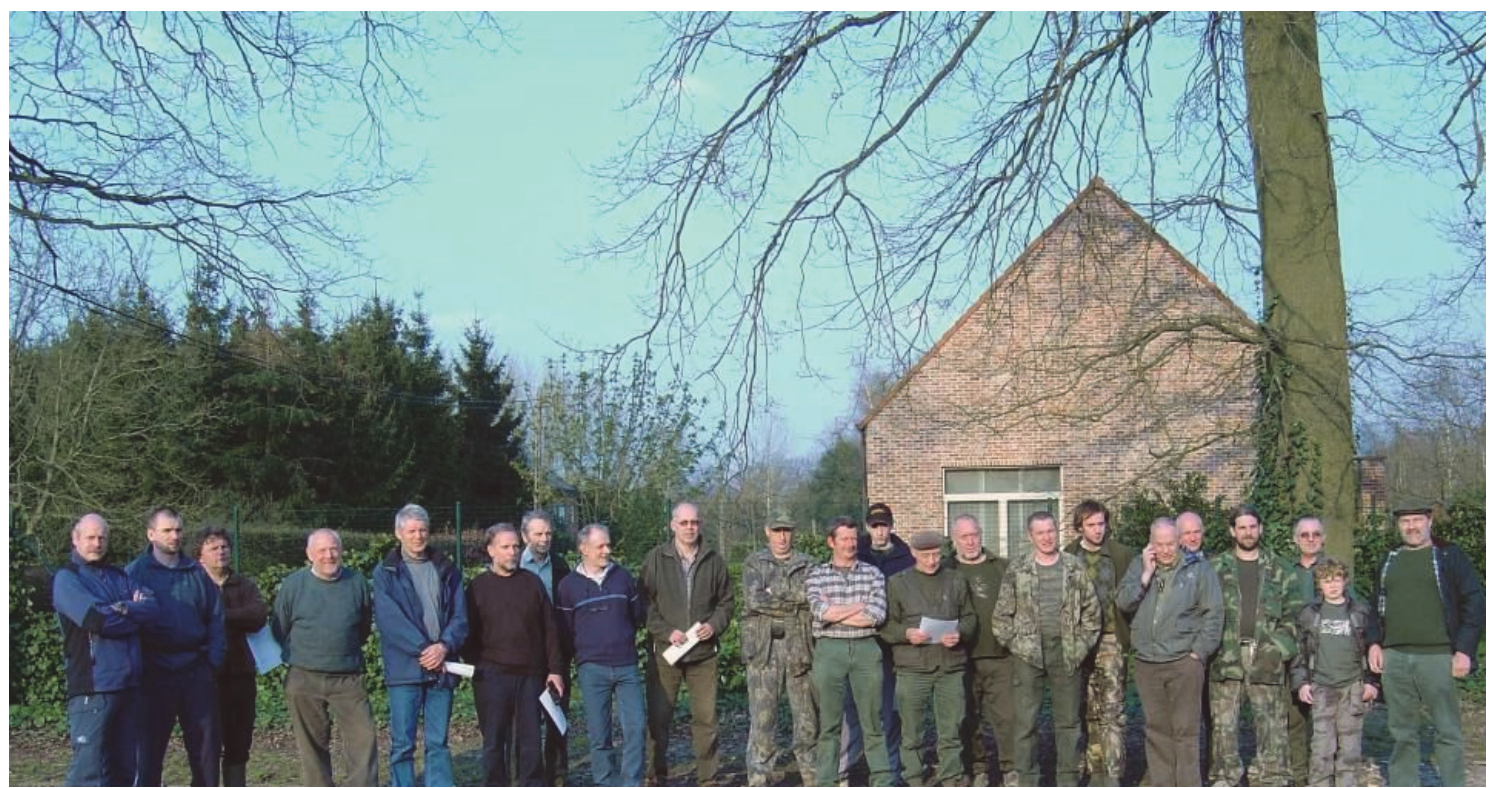

Groepsfoto van alle tellers bij aanvang van het project. 


\section{Samenvatting}

Na het beëindigen van de jacht in het 2000 ha grote 'boscomplex van de Merode' in 2005 werd de vraag gesteld naar de impact van deze stopzetting op de evolutie van zowel de lokale als de omliggende reepopulaties.

Om zicht te krijgen op deze ontwikkelingen werd in het jaar volgend op de stopzetting van de bejaging gestart met het opvolgen van de aantalsontwikkeling van de lokale populatie door middel van jaarlijkse en herhaalde kilometertellingen. De impact op de omliggende populaties werd nagegaan door middel van het analyseren van afschotgegevens en bio-indicatoren uit de omliggende WBE's.

Uit de kilometertellingen bleek dat de populatie over alle jaren heen stabiel is gebleven rond ongeveer 0,6 geobserveerde reeën per kilometer traject. Toch blijkt de situatie iets genuanceerder wanneer de verschillende deelgebieden afzonderlijk van elkaar worden geëvalueerd. In het meer zuidelijk deel dalen de kilometerindexen sterk na 2010, terwijl de waarden in het noordelijk deel toenemen. Ook in de omliggende WBE's worden sterke verschillen vastgesteld tussen die WBE's grenzend aan het noordelijk en het zuidelijk deel. Waar het afschot bij de laatsten over de jaren zeer sterk is afgenomen, is dat in de meer noordelijke WBE's niet het geval. De interpretatie van de bio-indicatoren is minder eenduidig, maar ook deze lijken er op te wijzen dat vooral de populatie in het noordelijk deel, net als in de brede omliggende regio, in de laatste jaren is toegenomen en het lokale ecologische draagvlak benadert.

Samengevat kan worden gesteld dat de populatie in het volledige complex stabiel is gebleven en niet de toename heeft gekend die bij een stopzetting van de bejaging verwacht kan worden. Wel hebben zich, mogelijks naar aanleiding van uitgevoerde beheerwerken in vooral het zuidelijk deel van het gebied en de eruit volgende veranderingen in habitatstructuur, sterke verschuivingen in de ruimtelijke verspreiding van ree in het volledige complex voorgedaan. Zowel de telgegevens van de kilometertellingen in het gebied als de afschotcijfers van de omliggende WBE's, en in mindere mate de bio-indicatoren van het geschoten reewild, geven aan dat de populatie zich deels van het zuidelijk deel van het complex naar het noordelijk deel heeft verplaatst. Het feit dat alle omliggende WBE's een daling van het afschot kenden en dat in het noordelijk deel van het complex de populatie verder toenam kan er ook op wijzen dat reeën, zoals werd verwacht, zich deels van de bejaagde naar de nietbejaagde zones hebben verplaatst, al is dit effect, door het mogelijke combinatie met het effect van de uitgevoerde beheerwerken op de verspreiding, niet eenduidig vast te stellen. 


\section{English abstract}

In 2005, all hunting activities within the 2000 ha forest complex 'de Merode' were stopped and the question arose which impact this decision would have on both local roe deer populations as on populations in the surrounding areas.

To answer this question, local roe deer numbers were monitored from 2006 on, using yearly and repeated transect censuses (kilometer index counts). The impact on nearby populations was assessed by analyzing game bag data and bio-indicators from the surrounding game management units (GMU's).

The kilometer indices showed that the population remained stable throughout the entire monitoring period at about 0,6 roe deer per kilometer transect. Nonetheless, the situations appears to be somewhat more complicated when data from the different subareas are evaluated separately. In the more southern part, kilometerindices decreased markedly from 2010 on, while the same indices increased in the northern part of the complex. In the surrounding GMU's, strong differences between GMU's bordering either the northern or southern part of the forest complex were also observed. In the latter GMU's, game bags for roe deer have dropped, while in the northern part, this was not the case. The interpretation of the data from various bio-indicators in the same GMU's is less unambiguous, but the values also seem to indicate that mainly the northern part of the population has increased to a point were roe deer numbers approach the ecological threshold.

In conclusion, it can be stated that the population in the entire complex has remained stable throughout the monitoring period and that it did not exhibit the population increase that was expected when hunting was stopped. It does appear, however, that, possibly as a result of forestry management actions in the southern part of the complex, strong shifts in the spatial distribution of roe deer within the complex have taken place. Both the census data as well as game bag data from surrounding GMU's, and to a lesser extent the bio-indicator values, indicate that the population distribution has partially shifted from the southern to the northern part of the complex. The fact that all surrounding GMU's have seen a decrease in game bag sizes and that the population size further increased in het northern part of the complex may also indicate that roe deer, as was expected, tend to move from hunted to hunting-free areas. This effect cannot be established unambiguously, however, due to the simultaneous impact of forestry management actions in the complex. 


\section{Lijst van figuren en tabellen}

Figuur 1.1: Situering van de verschillende deelgebieden van het complex de Merodebossen. ......................................10

Figuur 2.1: Overzichtskaart teltrajecten de Merodebossen en omstreken................................................................13

Figuur 2.2: Ligging van de aangrenzende wildbeheereenheden rond het Merodecomplex met aanduiding van de teltrajecten.

Figuur 3.1: Spreiding van de kilometerindexen per telling voor elk van de verschillende jaren...................................18

Figuur 3.2: Gemiddelde kilometerindex over alle trajecten per jaar (+/- 95\% betrouwbaarheidsinterval)........................18

Figuur 3.3: Gemiddelde jaarlijkse kilometerindex per gebiedscluster........................................................................19

Figuur 3.4: Evolutie van het afschot van ree per 100ha bos in de WBE's gelegen rondom het de Merodecomplex..........20

Figuur 3.5: Evolutie van het gerapporteerd leeggewicht en onderkaaklengte per WBE aangrenzend aan het Merodecomplex (gemiddelde $+/-95 \%$ betrouwbaarheidsinterval).

Figuur 3.6: Aantal vrouwelijke reeën met 0, 1, 2 of 3 embryo's (balken) en het gemiddeld aantal embryo's per drachtig ree $(x 10$, lijn)

Tabel 1: Aantal waargenomen reeën per traject per datum, met een totaal per datum (blanco=niet geteld). 


\section{Inhoudstafel}

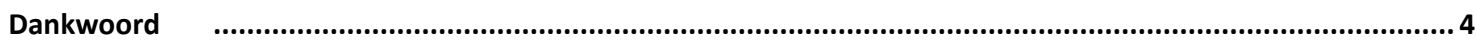

Samenvatting

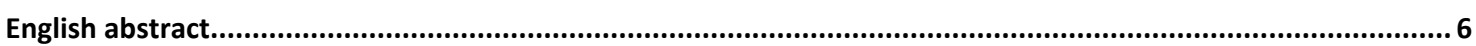

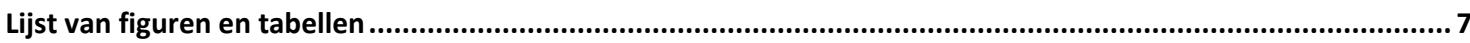

1

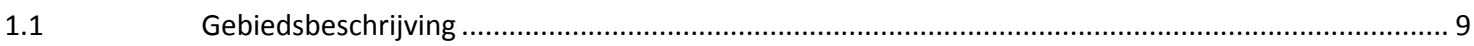

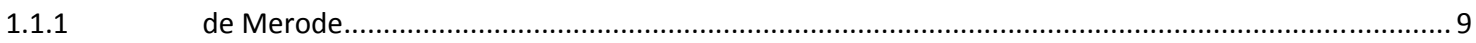

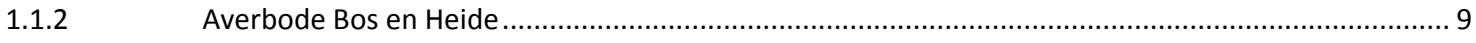

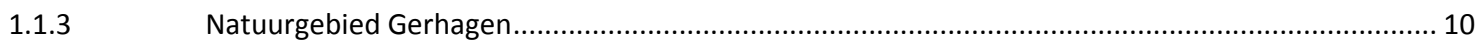

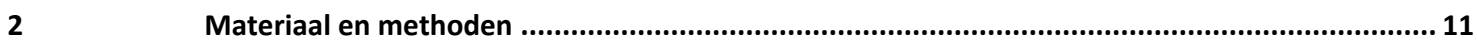

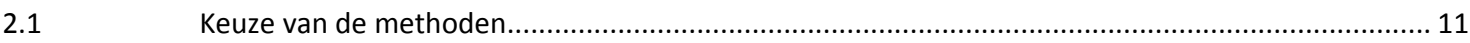

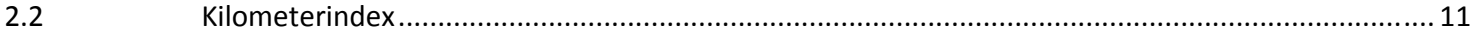

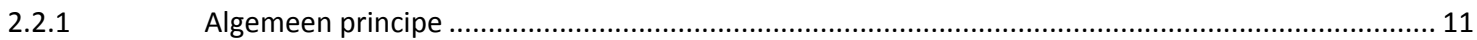

2.2.2 Tijdstip van de tellingen, periode van het jaar en het aantal herhalingen ....................................... 12

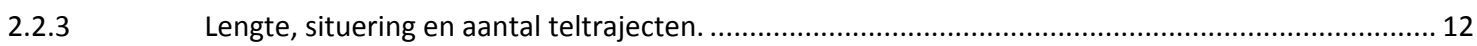

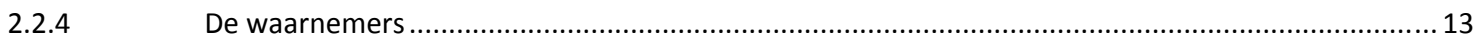

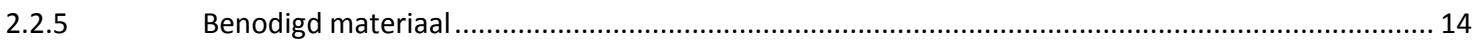

2.2.6 Verwerken van de data

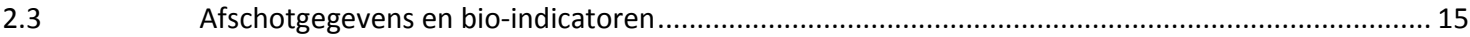

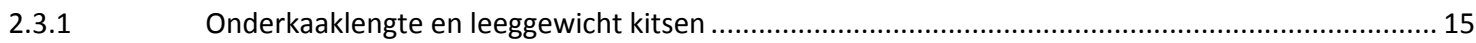

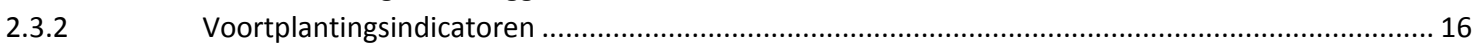

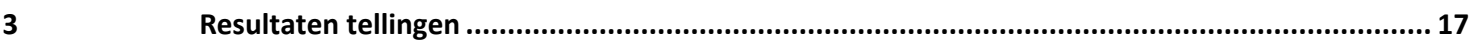

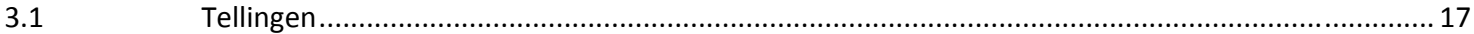

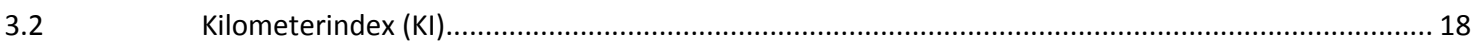

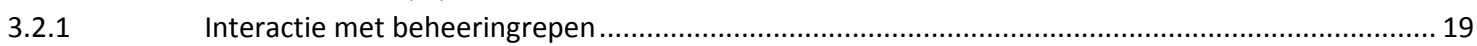

3.2.2 Vergelijking met afschot en bio-indicatoren omliggende WBE's .................................................. 20

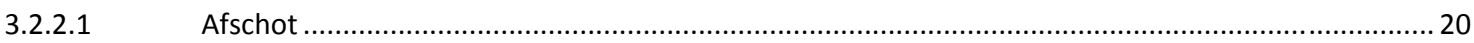

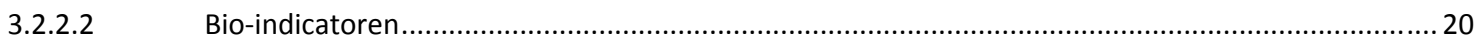

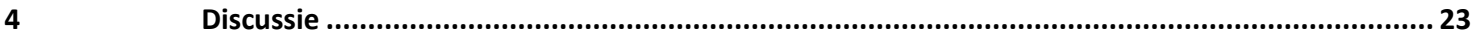

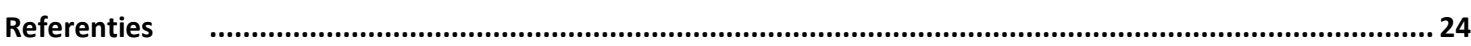

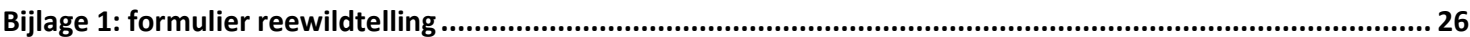




\section{$1 \quad$ Inleiding}

Door het beëindigen van de jacht (2005) in het 'boscomplex van de Merode', ontstond een situatie waarbij een relatief groot bosgebied van in totaal ongeveer 2000 ha niet meer verder bejaagd wordt. Hierdoor ontstond een verandering in het beheer die, in dit geval, vanaf het moment van de verandering kon opgevolgd worden. Vanuit verschillende kanten werd op dat moment de vraag gesteld naar hoe de impact van deze stopzetting van de bejaging op de populatie opgevolgd kon worden.

In het kader van mogelijke toekomstige analyses en mogelijke vraagstellingen, leek het zeker opportuun om zo snel mogelijk te starten met het verzamelen van de nodige gegevens. Dit laat toe de evolutie ten gevolge van het nulbeheer op te volgen vanaf het begin ervan en deze op een wetenschappelijk onderbouwde manier te documenteren, om zo, vanuit een concrete situatie van op het terrein (case study), lessen te kunnen trekken voor de toekomst en voor andere gebieden.

De concrete onderzoeksvragen waren onder andere:

- Hoe zal de populatie binnen het niet bejaagd gebied verder evolueren ?

- Zal dit een effect hebben op de populaties buiten het niet-bejaagd gebied en zo ja welke ?

- Is er een sterke migratie (emigratie/immigratie) tussen het niet bejaagd en bejaagd gebied ?

- Resulteert dit in een toename van verkeersongelukken?

\subsection{Gebiedsbeschrijving}

\subsection{1 de Merode}

Hertberg, Varenbroek en Helschot zijn drie bosgebieden die vroeger toebehoorden aan de familie de Merode. Ze liggen samen met het Sterschotsbos in het zuidoosten van de provincie Antwerpen, grotendeels op het grondgebied van de gemeenten Westerlo en Herselt (Figuur 1.1, omgeving trajecten 1-7 op Figuur 2.1). In 2000 bood prins de Merode zowat 1500 ha van zijn eigendommen te koop aan. Het grootste deel hiervan was bebost natuurgebied. Om versnippering van het gebied tegen te gaan, kocht de Vlaamse Landmaatschappij (VLM) in januari 2004 het volledige gebied aan, waartoe ook het complex Averbode Bos en Heide behoorde (zie 1.1.2). Dit gebeurde in samenwerking met de Vlaamse regering, het Agentschap voor Natuur en Bos (ANB), de gemeentebesturen van Geel, Westerlo, Herselt, Laakdal, Tessenderlo en Scherpenheuvel-Zichem en de verenigingen Kempens Landschap vzw en Natuurpunt vzw. Het ANB is momenteel de belangrijkste eigenaar en beheerder van de vier bovenvermelde bosrijke natuurgebieden van de Merode.

Hertberg is met zijn 310 ha het grootste van de vier bosgebieden. Al eeuwenlang was dit een bebost gebied, met voornamelijk Corsicaanse en grove den. Het 65 ha grote Sterschotsbos bestaat ook voor ongeveer de helft uit grove en Corsicaanse den en voor een derde uit loofhout. Enkele terreinen, gelegen in een voormalig militair domein, bestaan uit akkers, weilanden en vijvers. Varenbroek is een 62 ha groot bos dat tot 2003 een privaat jachtterrein van de Merodefamilie was. Zomereik en oude wintereik domineren dit bos. lets ten zuiden van Varenbroek ligt Helschot. Dit uiterst waardevolle bosgebied van 60 ha is bestempeld als bosreservaat. Zomer- en wintereik zijn de meest voorkomende boomsoorten naast populier en wat naaldhout.

In de gevarieerde boscomplexen van de Merode worden naast de bosplanten die typisch zijn voor oude bossen ook verschillende zeldzame plantensoorten aangetroffen zoals kleine ratelaar en valse kamille. Ook onder de fauna in de Merodebossen vinden we zeldzame soorten zoals kleine ijsvogelvlinder en verscheidene libellensoorten.

\subsubsection{Averbode Bos en Heide}

Bron: Natuurpunt 2012

Midden in de driehoek Aarschot, Diest, Westerlo, rondom de Norbertijnenabdij van Averbode, ligt het bosgebied Averbode Bos en Heide, 575 ha groot (Figuur 1.1, omgeving trajecten 10-16 op Figuur 2.1). Ook Averbode Bos en Heide was ooit één van de deelgebieden van het uitgestrekte domein van de prinsen de Merode. Het werd in 2006 van de VLM doorverkocht aan Natuurpunt. Het gebied word gekenmerkt door een grote landschappelijke 
verscheidenheid met bossen, graslanden, heiderelicten, duin- en stuifzandvegetaties, lineaire landschapselementen, struwelen, vennen en wijers. Als gevolg van het LIFE-herstelproject is het gebied gedurende de projectperiode sterk veranderd (Natuurpunt 2012). De naaldbossen worden voor een deel omgevormd tot wintereiken-beukenbossen en zomereiken-berkenbossen en tot open naaldbos met ongelijkjarige opbouw en dus grote diversiteit.

De bossen werden ook deels omgevormd tot zeldzame, Europese habitats zoals natte en droge heide, duinen en vennen. Ook is het gebied veel natter geworden door het dempen van drainagegrachten en het plaatsen van stuwen, wat heeft geleid tot het herstel van talrijke vennen. Intensieve kap- en plagwerken hebben dan weer tot een meer open landschap met heideherstel geleid. Daarmee gepaard is natuurlijk ook de vegetatie sterk gewijzigd en zijn nu enkele zeldzame soorten zoals liggende vleugeltjesbloem, veelstengelige waterbies, moeraswolfsklauw, fraai- en moerashersthooi in het gebied aanwezig. In het gebied werden tot nu toe 43 soorten libellen en 30 soorten dagvlinders waargenomen en zijn broedgevallen genoteerd van onder andere nachtzwaluw en boomleeuwerik.

\subsubsection{Natuurgebied Gerhagen}

Bron: Werkgroep Ecologie Tessenderlo vzw 2015

Het domein Gerhagen situeert zich in het gehucht Schoot (Tessenderlo) en heeft een oppervlakte van 945 ha (Figuur 1.1, omgeving trajecten 8-9 op Figuur 2.1). Meer dan de helft is bebost met voornamelijk grove en Corsicaanse den en op enkele plaatsen ook zeeden. Via een gewijzigd bosbeheer wordt er meer aandacht besteed aan het loofhout. In het lager gelegen gedeelte komen weiden en akkers voor. Centraal in het gebied bevinden zich twee vennen, enkel gevoed door regenwater. Deze hangvennen zijn zuurstofarm en nogal zuur, omwille van het stilstaande water en de ondoordringbare bodem. Het zuidelijke deel van het gebied bestaat vooral uit bossen en heide met stuifzanden. Sinds enkele jaren worden er intensieve beheerwerken uitgevoerd in het gebied, waarbij vooral veel Corsicaanse den, Amerikaanse eik en Amerikaanse vogelkers werd geveld. Daarnaast zorgden kap- en plagwerken ook hier voor plaatselijk herstel van open heidevlaktes. De resultaten van deze beheerwerken hebben ook hier geleid tot de terugkeer van een aantal opvallende soorten zoals: bruine en witte snavelbies, kleine en ronde zonnedauw, moeraswolfsklauw, klapekster, boomleeuwerik en nachtzwaluw, maar ook tot een meer open gebied dat minder dekking levert aan de aanwezige reeën.

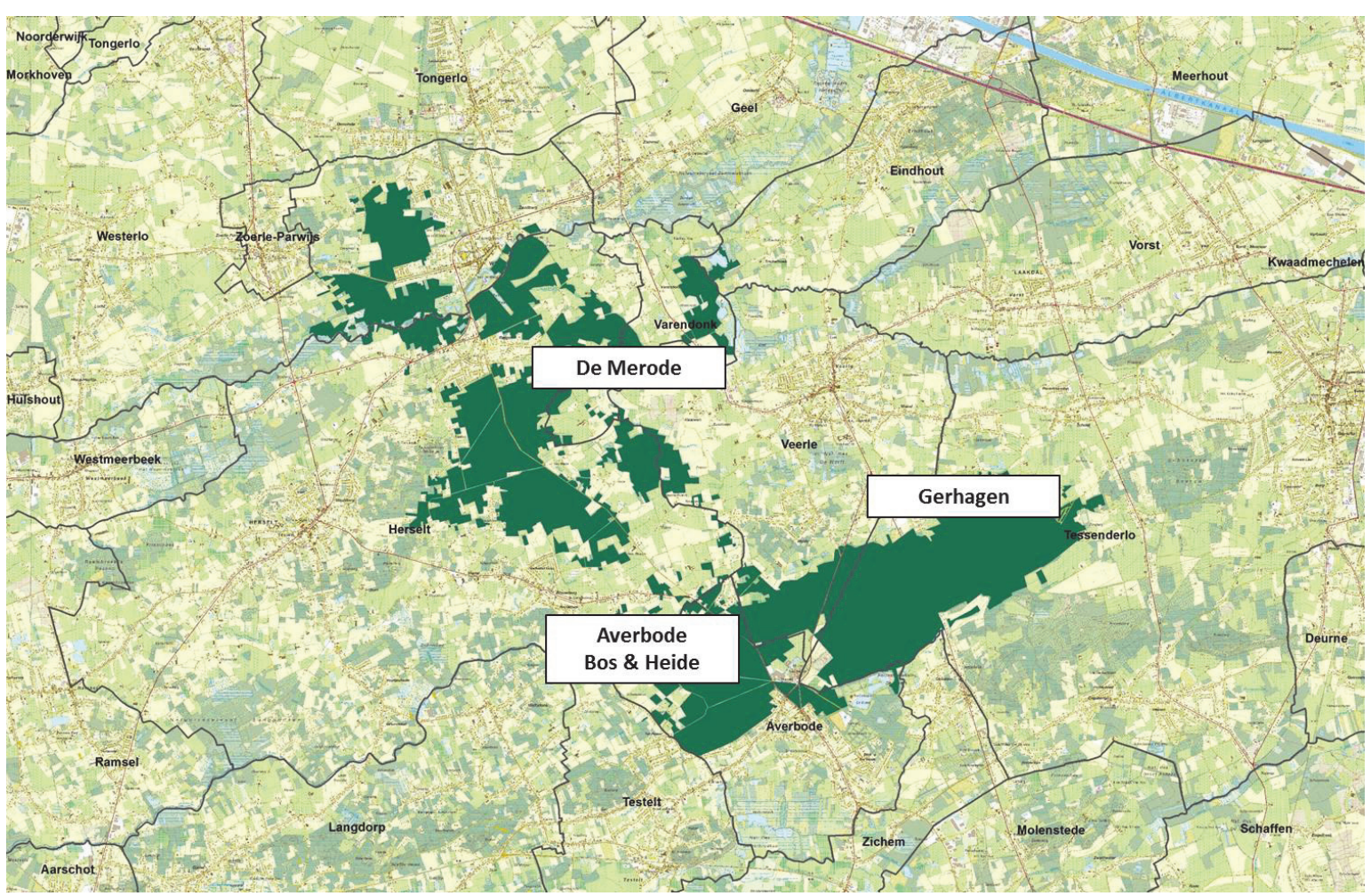

Figuur 1.1: Situering van de verschillende deelgebieden van het complex de Merodebossen. 


\section{Materiaal en methoden}

\subsection{Keuze van de methoden}

In eerste instantie werd geopteerd om vooral de populatiegrootte binnen het gebied nauw op te volgen. Omdat absolute telmethoden voor reepopulaties niet voorhanden zijn, werd gekozen voor een indexmethode die toelaat de verandering in de aantallen op een gevalideerde manier na te gaan. Hiervoor viel de keuze op kilometertellingen, een methode die in het verleden voor ree gevalideerd werd als indexmethode. Deze validatie gebeurde door langdurig onderzoek op populaties in gebieden waar de reële veranderingen in de populatiegrootte gekend waren en gemanipuleerd konden worden (Ballon 1999; Delorme 1989, 2003; Vincent \& Bideau 1982, Vincent et al. 1991, 1995, 1996). Daarenboven wordt de methode actueel al op enkele plaatsen in België gebruikt voor het monitoren van reewildpopulaties.

Voor het inschatten van de impact van de populatieontwikkeling in het gebied op de omliggende gebieden werden gegevens uit de omliggende wildbeheereenheden (WBE's) verzameld. De evolutie van zowel het uitgevoerde afschot als van de verschillende bio-indicatoren uit dit afschot, geven zowel een beeld van de populatieontwikkeling als van de toestand van de populatie in deze WBE's. Er werd geopteerd om de fecunditeit, de onderkaaklengte van de kitsen, het leeggewicht van de kitsen en het aandeel reproducerende geiten als bio-indicatoren op te volgen, zoals gesuggereerd door Huysentruyt \& Casaer (2012).

Biologische gegevens uit het gebied zelf waren niet beschikbaar zodat de rechtstreekse impact op de populatietoestand binnen het gebied niet kon worden nagegaan. Ook concrete cijfers over verkeersslachtoffers rond het gebied waren niet voorhanden.

\subsection{Kilometerindex}

\subsubsection{Algemeen principe}

Het principe van de kilometertelling is vrij eenvoudig. Gedurende de wintermaanden worden vooraf vastgelegde trajecten te voet afgelegd. Aan de hand van een standaard opnameformulier (Bijlage 1) worden bij elke waarneming van reeën de volgende gegevens, zoveel mogelijk, genoteerd:

- $\quad$ hoeveel dieren gezien werden;

- $\quad$ of het jonge of oude dieren zijn;

- $\quad$ of het mannelijke of vrouwelijke dieren zijn;

- $\quad$ het moment van de waarneming;

- de plaats van de waarneming (op kaart aangeduid).

Het aantal getelde dieren wordt zowel beïnvloed door het aantal in het gebied aanwezige dieren, als door de waarnemingskans. De waarnemingskans (de kans om een ree dat aanwezig is waar te nemen) wordt, op zijn beurt, niet alleen beïnvloed door de aanwezige vegetatie in het gebied (Casaer 2003), maar ook door de interne verdeling van de reeën in het gebied. Om geen vertekend beeld te verkrijgen na verloop van tijd worden de te volgen trajecten op een willekeurige manier over alle bestandstypen die in het gebied voorkomen verdeeld. De trajecten worden jaarlijks vier maal herhaald en worden hierbij telkens allemaal gelijktijdig afgewandeld.

Aan de hand van een kilometerindex wordt niet geprobeerd om een beeld te krijgen van het totaal aantal reeën, maar enkel van de veranderingen in het aantal reeën in een bepaald gebied. De interpretatie van de kilometertellingen is alleen zinvol na verloop van een aantal jaren.

Als instrument bij het beheer van reewildpopulaties is het daarom te verkiezen niet jaarlijks maar pas om de drie jaar (of langer) de resultaten van de kilometerindex te gebruiken om het beheer bij te sturen. 


\subsubsection{Tijdstip van de tellingen, periode van het jaar en het aantal herhalingen}

Volgens het Office National de la Chasse et de la Faune Sauvage (ONCFS) (2015), afgaand op voorgaande richtlijnen van de zogenaamde Groupe Chevreuil (1991), een Frans samenwerkingsverband tussen onderzoeksgroepen die zich bezig houden met onderzoek naar het beheer van reewild, blijkt de optimale periode voor het uitvoeren van de kilometertelling in maart te liggen. Gedurende deze periode:

- $\quad$ is de zichtbaarheid in het bos maximaal aangezien de struiklaag nog zonder bladeren staat;

- bevinden de reeën zich in groep, zijn ze nog niet territoriaal en hebben beide geslachten een even grote kans om gezien te worden.

Dit laatste wordt echter gedeeltelijk tegengesproken door Ellenberg (1974) die als enige periode waarin de waarnemingskans voor beide geslachten gelijk geschat wordt, de periode tussen september en november aangeeft. Verder wordt door het ONCFS (2015) aangegeven dat de tellingen best 's morgens of 's avonds plaatsvinden en best zo goed mogelijk verspreid worden over de totale periode waarin de tellingen plaatsvinden.

Omwille van het jachtseizoen op geiten en kitsen in Vlaanderen (in het verleden van 15/01 - 15/03, actueel 1/1 31/03) werd al enkele jaren geleden voorgesteld de periode voor de kilometertellingen in Vlaanderen twee maanden naar achter te verschuiven (half maart - mei). De evaluatie van de resultaten uit een eerste testjaar van reewildtellingen in het Zoniënwoud gaf aan dat het gebruik van acht herhalingen niet resulteerde in een noemenswaardige daling van het betrouwbaarheidsinterval. In tegendeel bleek het spreiden van de tellingen over een dergelijk lange periode (van acht weken) eerder nadelig. Het is namelijk zo dat, in deze periode van het jaar, de waarnemingsomstandigheden erg veranderlijk zijn door de sterke vegetatieontwikkeling aan het eind van de winter. Daardoor werd op basis van deze resultaten besloten slechts vier tellingen uit te voeren (Casaer \& Malengraux 2008, Huysentruyt et al. 2015). In het Zoniënwoud, waar geen jacht is, werd met telkens deze vier tellingen gestart in het begin van de maand maart. In de Merode werd besloten twee weken later te starten, na het eind van de geiten- en kitsenjacht. Hierdoor starten de tellingen telkens onmiddellijk na het beëindigen van de jacht op geiten en kitsen op 15 maart en lopen ongeveer tot 15 april. Indien men zich beperkt tot vier tellingen kunnen de tellingen onmiddellijk na 15 maart starten en plaatsvinden in de vier of vijf daaropvolgende weken. Omwille van de continuïteit werd de aanvangsdatum van de tellingen niet gewijzigd met de recente aanpassing van de openingstijden.

Uit eerdere testen (Casaer nt. gepubl.) blijkt dat er geen verschil waar te nemen is tussen trends op basis van tellingen uitgevoerd tussen januari en maart en deze op basis van tellingen uitgevoerd tussen 15 maart en 15 mei. Deze observaties maken het verantwoord dezelfde tellingmethode te hanteren als in Frankrijk maar de periode twee maanden te verschuiven, zonder nieuw validatieonderzoek uit te voeren met populaties waarvan de absolute grootte gekend is.

\subsubsection{Lengte, situering en aantal teltrajecten.}

De verdeling van de trajecten over het volledige gebied moet garanderen dat alle bestandstypes en delen van het boscomplex bemonsterd worden. Het aantal na te streven kilometer traject per oppervlakte-eenheid situeert zich rond 1 traject van ongeveer 5 à $7 \mathrm{~km}$ per 200 ha. Als stelregel wordt aangenomen dat er per 100 ha ongeveer $3 \mathrm{~km}$ traject aangeduid wordt en dat de trajecten maximaal $5 \mathrm{~km}$ lang zijn. Op deze manier kan elke teller in ongeveer anderhalf tot twee uur zijn traject uitvoeren. Minder dan 1 parcours per 200 ha levert onbetrouwbare resultaten op (Groupe Chevreuil 1991).

Anderzijds stelt de Groupe Chevreuil (1991) dat wanneer de tellingen simultaan gebeuren over heel het boscomplex, de teltrajecten voldoende ver van elkaar gesitueerd moeten zijn om dubbeltellingen te vermijden (opgejaagde dieren die van het ene teltraject naar het andere lopen).

De concrete teltrajecten werden samen met de deskundigen van de verschillende beheerders of belangengroepen uitgewerkt (boswachters, jagers, natuurvereniging, ...). Deze trajecten zijn afzonderlijke lussen en werden uitgewerkt op basis van bestaande elementen (wegen, dreven, exploitatiewegen, ...).

In 2006 werd in de Merode gestart met 5 teltrajecten (traject 1-5, Figuur 2.1), met een totale lengte van 15,1 km. In samenwerking met de plaatselijke wildbeheereenheden (WBE's) en Natuurpunt werd in 2007 het aantal trajecten 
uitgebreid van 5 naar 16, nu met een totale lengte van 58,6 km voor het geheel van om en bij de 2000 ha bosgebied. Hierdoor wordt een dichtheid bekomen van 2,93 km teltraject per 100 ha bos, met een gemiddelde lengte van 3,7 km per traject, waardoor de opzet aan de gestelde randvoorwaarden voldoet.

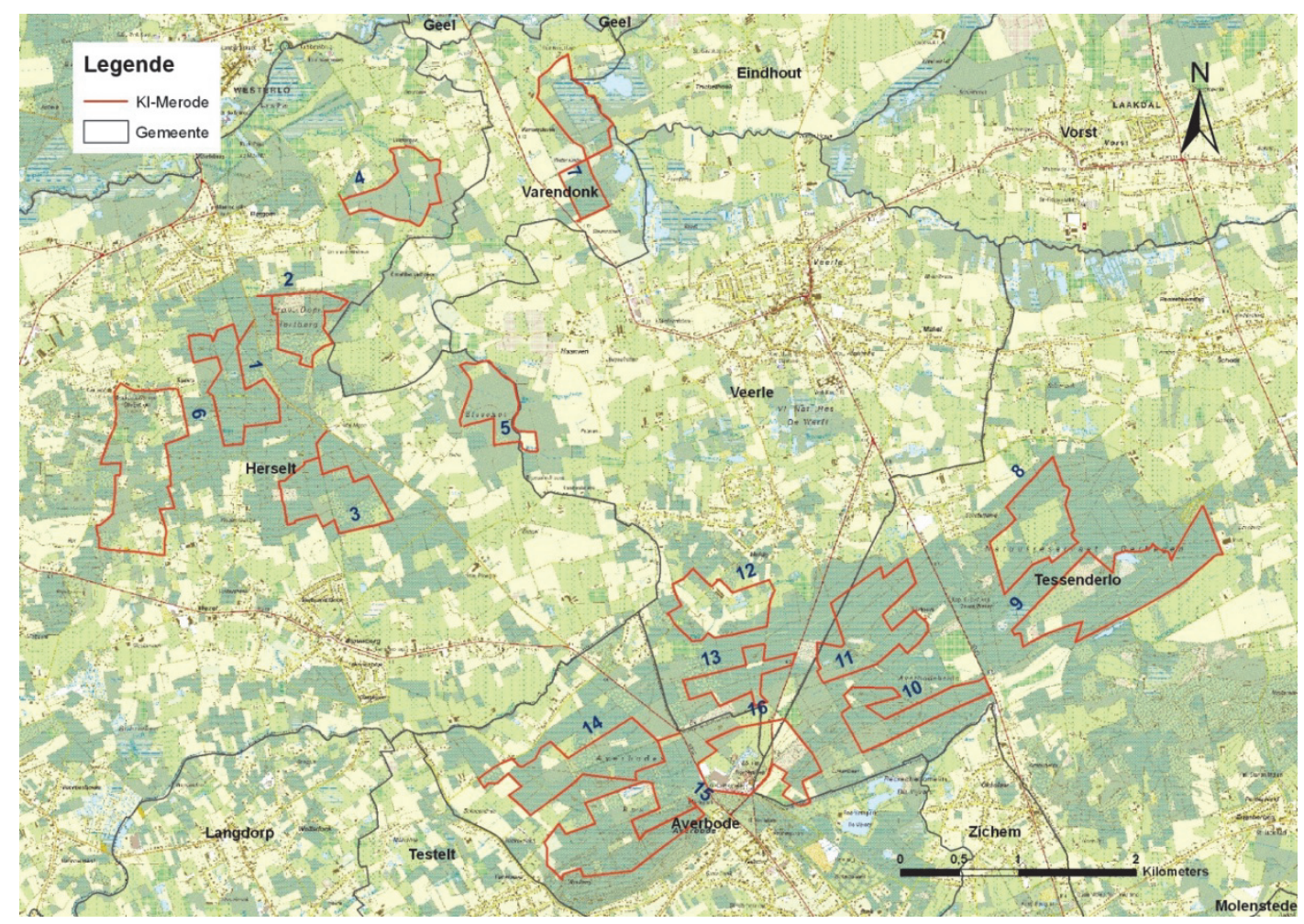

Figuur 2.1: Overzichtskaart teltrajecten de Merodebossen en omstreken.

\subsubsection{De waarnemers}

Wanneer wordt nagestreefd dat alle trajecten simultaan worden geteld, moeten er minimaal evenveel waarnemers als trajecten zijn.

Een mogelijk probleem is het effect van de waarnemers op het aantal waargenomen reeën omwille van hun individuele waarnemingscapaciteiten. Delorme (1989) toonde aan dat het aantal waargenomen reeën beïnvloed wordt door de waarnemingscapaciteiten (o.a. bepaald door de ervaring) van de waarnemers. Daarom wordt aangeraden zoveel mogelijk dezelfde waarnemers te gebruiken gedurende de volledige duur van het monitoringsproject of de opvolging van de populatiegrootte in het kader van het beheer van een reewildpopulatie, of anders de waarnemers ad random toe te kennen aan de verschillende trajecten bij elk van de bezoeken.

Voor de opvolging zijn er twee mogelijke scenario's denkbaar:

1. Dezelfde persoon voert alle jaren, alle tellingen voor een welbepaald traject uit. In dit geval moet er een garantie bestaan dat deze persoon elk jaar op alle teldata van dat jaar beschikbaar zal zijn en dit gedurende meerdere jaren.

2. Er wordt gebruik gemaakt van een 'rotatiesysteem' waarbij de waarnemers telkens een ander traject tellen. Omwille van praktische en logistieke redenen (o.a. verkeersproblematiek) worden kleinere subgroepen ( 5 trajecten) gemaakt waarbinnen wordt geroteerd. Op deze manier kent elke teller na één jaar ook alle trajecten die hij of zij dient uit te voeren.

In de Merode- en omliggende bossen werd gebruik gemaakt van de 2 hier boven vermelde scenario's. Voor 4 trajecten $(1,2,4$ en 5) wordt er gebruik gemaakt van het rotatiesysteem en voor alle andere was het telkens dezelfde persoon die een vast traject voor zijn rekening nam. 


\subsubsection{Benodigd materiaal}

Elke waarnemer dient voorzien te zijn van een uurwerk, een verrekijker en een potlood. Daarnaast krijgt elke waarnemer een opnameformulier (Bijlage 1) met op de achterzijde een kopij van de topografische kaart waarop het te volgen teltraject is aangeduid. Dit traject dient steeds nauwgezet gevolgd te worden (Groupe Chevreuil 1991).

Bij elke waarneming van een ree of groep van reeën (= bij elk visueel contact) wordt een volgnummer genoteerd voor de waarneming. Dit nummer wordt op de juiste plaats op de kaart aangebracht. Het aantal dieren - opgedeeld naar bok, geit, kits, onbepaald - wordt genoteerd, alsook het uur van de waarneming. De opdeling naar leeftijd- en geslachtklasse is op zich voor het berekenen van de kilometerindex niet noodzakelijk, maar laat eventueel bijkomende analyses toe.

\subsubsection{Verwerken van de data}

Per traject kan per telling een kilometerindex berekend worden. Deze wordt berekend door het aantal waargenomen reeën te delen door het totaal aantal afgelegde kilometers.

$$
K I p_{n m}=\frac{\text { Totaal aantal waargenomen reeën op traject } \mathrm{i} \text { bij telling } \mathrm{x}}{\text { Totaal aantal kilometers van traject } \mathrm{i}}
$$

Waarbij $n$ staat voor het totaal aantal trajecten en $m$ voor het totaal aantal tellingen. Per serie, of reeks, bestaande uit alle trajecten samen op een bepaalde dag kan de kilometerindex voor die telling (of reeks) berekend worden. Deze is het gemiddelde over alle parcours die op die dag geteld worden.

$$
K I r_{m}=\frac{\text { Som van KIp's van de uitgevoerde trajecten }}{\text { aantal uitgevoerde trajecten }(\mathrm{n})}
$$

Tot slot kan de kilometerindex berekend worden, voor een bepaald jaar in een bepaald gebied, door het gemiddelde te nemen over alle tellingen (reeksen) heen.

$$
\text { KIjaar }=\frac{\text { Som van alle KIr's }}{\text { totaal aantal uitgevoerde reeksen }(\text { tellingen })(\mathrm{m})}
$$

Doordat de tellingen verschillende keren uitgevoerd worden (minimaal 4 keer binnen een beperkte periode), kan ook jaarlijks een betrouwbaarheidsinterval berekend worden. Dit is noodzakelijk om de kilometerindexen tussen de verschillende jaren op een statistisch verantwoorde manier te kunnen vergelijken. Het spreekt voor zich dat het verhogen van het aantal keren dat een volledige set van trajecten geteld wordt (m.a.w. het verhogen van het aantal reeksen $m$ ), ertoe leidt dat het betrouwbaarheidsinterval kleiner wordt. Jaarlijks kan aan de hand van het betrouwbaarheidsinterval de ondergrens en de bovengrens voor de jaar-KI berekend worden. Grote verschillen in kilometerindexen tussen de verschillende trajecten kunnen het resultaat zijn van verschillen in reewilddensiteiten, maar ook van verschillen in waarnemingskansen tussen de verschillende deelgebieden in het boscomplex. 


\subsection{Afschotgegevens en bio-indicatoren}

De verschillende afschotgegevens en bio-indicatoren werden verzameld in de vier WBE's die grenzen aan minstens een van de deelgebieden van het Merodecomplex. Het gaat hier om WBE's Laakdaal, Tessenderlo, Demervallei en Zuiderkempen (Figuur 2.2). De start van de analyseperiode werd gelijk genomen met de start van de kilometertellingen (2006) en de gegevens werden geanalyseerd tot en met 2014.

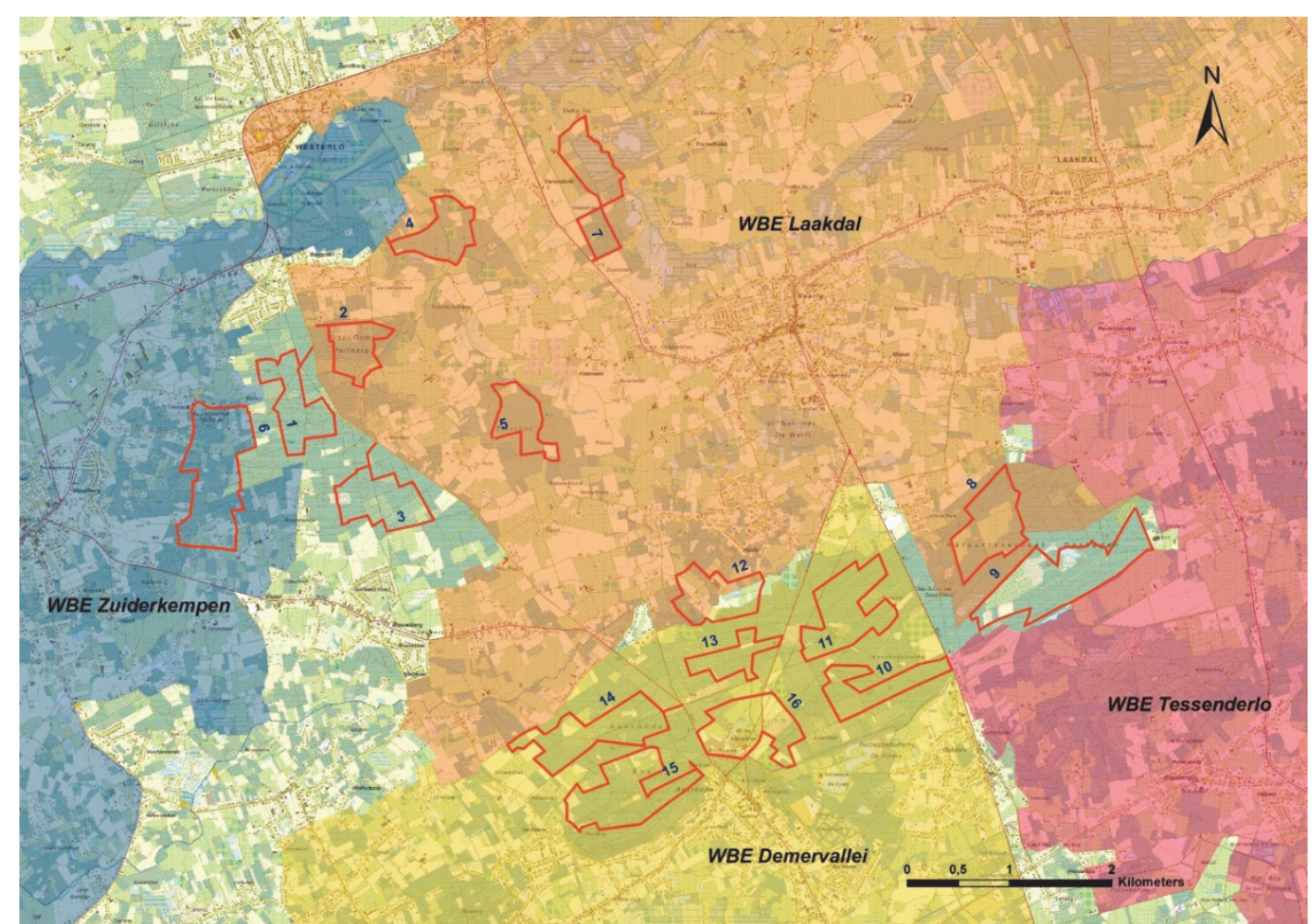

Figuur 2.2: Ligging van de aangrenzende wildbeheereenheden rond het Merodecomplex met aanduiding van de teltrajecten.

\subsubsection{Onderkaaklengte en leeggewicht kitsen}

Het aantal lobben van de derde premolaar (P4) is een eenvoudige en bij jagers goed gekende methode om kitsen te kunnen herkennen op basis van de tandwissel. Dit maakt dat deze categorie dieren niet alleen eenduidig herkenbaar zijn als kits maar ook in een gegeven afschotjaar steeds tot dezelfde cohorte behoren. Hierdoor vormt deze klasse van dieren een ideale categorie om bio-indicatoren bij op te volgen. De gemeten indicatoren zijn immers naast het resultaat van omgevingsvariabelen ook de resultante van individuele variatie en van leeftijds-, geslachts- en cohorte-effecten. Door de analyses te beperken tot de kitsen wordt deze variatie dan ook sterk beperkt. Idealiter wordt daarenboven ook opgedeeld per geslacht en wordt er gecorrigeerd voor afschotdatum (Blant \& Gaillard 2004, Huysentruyt \& Casaer 2012), maar bij een beperkte set van gegevens, zoals hier het geval is, is dit niet altijd mogelijk.

Het gebruik van onderkaaklengte van een kits als indicator voor de toestand van de populatie is gebaseerd op de vaststelling dat deze onderkaaklengte daalt met stijgende reedichtheden (Ballon 1999). Er bestaat een sterke relatie tussen de onderkaaklengte en het lichaamsgewicht van een kits. Onderkaaklengtes kunnen hierdoor vaak individuele groeiverschillen eerder dan conditieverschillen uitdrukken (Blant \& Gaillard 2004). Toch blijkt de lengte van de onderkaak bij reeën onder 1 jaar, naast een indicator voor de individuele constitutie van het ree, in zijn globaliteit een goede weergave van de relatie tussen populatie en de draagkracht van de omgeving te zijn (Hewison et al. 1996 in ONC 1996). In deze analyses werden de onderkaaklengtes zoals opgegeven in de meldingsformulieren (tot op $1 \mathrm{~mm}$ nauwkeurig) gebruikt. Daarbij werd het gemiddelde van alle gekende onderkaaklengtes (links en/of rechts) per reekits berekend. Er werd geen correctie voor afschotdatum toegepast. 
Ook het gewicht van reekitsen blijkt een uitstekende indicator om de toestand van een populatie op te volgen (Kjellander 2000, Kjellander et al. 2006, Toïgo et al. 2006). Het lichaamsgewicht van reekitsen blijkt immers sterk vatbaar voor schommelingen van de omgevingsvariabelen (Hanks 1981, Petorelli et al. 2001, Hewison et al. 2002, Kjellander et al. 2006). Een van de voornaamste redenen hiervoor is het feit dat de kwaliteit en de kwantiteit van het voedsel dat voor de moeder beschikbaar is gedurende het laatste derde van de dracht mee het geboortegewicht van de kitsen beïnvloedt (Blant \& Gaillard 2004, Kjellander et al. 2006). Als maat voor het lichaamsgewicht van reekitsen werd geopteerd voor het ontweid gewicht, zoals dat door de jagers op het meldingsformulier wordt gemeld. Hierbij werd een precisie tot op $10 \mathrm{~g}$ op het meldingsformulier voorzien maar vaak werd tot op $1 \mathrm{~kg}$ nauwkeurig afgerond.

\subsubsection{Voortplantingsindicatoren}

Ook het reproductiesucces wordt bij hoefdieren vaak gebruikt om de populatietoestand in verhouding tot de ecologische draagkracht van een gebied te beschrijven. Hiervoor worden traditioneel twee verschillende parameters gebruikt: de fecunditeit (het aantal kitsen per drachtige geit) en het aandeel zich voortplantende dieren (per jaar en per leeftijdsklasse) (Gaillard 1988). Het gebruik van het aandeel reproductieve vrouwelijke reeën is gebaseerd op het feit dat onder slechte omstandigheden een aandeel smalreeën en jonge geiten geen voldoende hoog lichaamsgewicht behalen om aan de reproductie deel te nemen (Gaillard et al. 1992; ONC 1999; Kjellander et al. 2006). Ook het gemiddeld aantal kitsen per reproducerende geit daalt bij sterke stijgingen in densiteiten (Vincent \& Bideau 1992, ONC 1999). Dit is gerelateerd aan het feit dat zwaardere geiten grotere worpen produceren dan lichtere geiten (Hewison 1996 in Cederlund et al. 1998). Opnieuw geldt hier dat het vooral het reproductiesucces bij smalreeën is dat in dergelijke gevallen snel afneemt (Cederlund et al. 1998).

De fecunditeit werd bepaald als het aantal embryo's per reproducerende geit/smalree (Gaillard 1988). Voor het aandeel reproducerende dieren werd de verhouding genomen van het aantal geiten/smalreeën zonder embryo's ten opzichte van het aantal drachtige dieren. Voor het bepalen van beide indicatoren werd gebruikt gemaakt van het aantal embryo's dat per geit/smalree, zoals dat op het meldingsformulier werd ingevuld. Hierbij moet worden opgemerkt dat in de jaren voor 2007 bij geiten en smalreeën waarvan het aantal embryo's onbekend was steeds standaard de waarde nul werd gegenereerd in de databank, in plaats van een blanco veld, waardoor voor die periode beide indicatoren niet correct te bepalen zijn. 


\section{Resultaten tellingen}

\subsection{Tellingen}

In Tabel 1 worden de getelde aantallen per traject en per datum weergegeven.

\begin{tabular}{|c|c|c|c|c|c|c|c|c|c|c|c|c|c|c|c|c|c|}
\hline \multirow{2}{*}{$\begin{array}{l}\text { Datum } \\
\text { Datum }\end{array}$} & \multicolumn{16}{|c|}{ Traject } & \multirow[b]{2}{*}{ Totaal } \\
\hline & 1 & 2 & 3 & 4 & 5 & 6 & 7 & 8 & 9 & 10 & 11 & 12 & 13 & 14 & 15 & 16 & \\
\hline 23-mrt-06 & 2 & 0 & 2 & 6 & 3 & & & & & & & & & & & & 13 \\
\hline 30-mrt-06 & 3 & 0 & 1 & 2 & 2 & & & & & & & & & & & & 8 \\
\hline 20-apr-06 & 0 & 3 & 1 & 5 & 8 & & & & & & & & & & & & 17 \\
\hline 24-apr-06 & 0 & 1 & 2 & 2 & 5 & & & & & & & & & & & & 10 \\
\hline 19-mrt-07 & 1 & 1 & 0 & 1 & 1 & 6 & 4 & 0 & 7 & 4 & 3 & 0 & 2 & 0 & 2 & 3 & 35 \\
\hline 26-mrt-07 & 5 & 1 & 0 & 3 & 3 & 7 & 7 & 0 & 3 & 2 & 0 & 2 & 2 & 8 & 2 & 3 & 48 \\
\hline 02-apr-07 & 3 & 0 & 0 & 2 & 0 & 3 & 4 & 0 & 3 & 9 & 5 & 1 & 3 & 3 & 5 & 1 & 42 \\
\hline 16-apr-07 & 1 & 1 & 0 & 4 & 0 & 1 & 7 & 0 & 0 & 2 & 4 & 2 & 0 & 6 & 0 & 10 & 38 \\
\hline 17-mrt-08 & 0 & 0 & 0 & 5 & 1 & 3 & 1 & 0 & 0 & 1 & 0 & 0 & 6 & 0 & 8 & 3 & 28 \\
\hline 01-apr-08 & 0 & 4 & 0 & 4 & 1 & & 5 & & 0 & 3 & 4 & 1 & 4 & 0 & 2 & 7 & 35 \\
\hline 07-apr-08 & 0 & 0 & 1 & 3 & 1 & 0 & 6 & 1 & 0 & 4 & 0 & 0 & 0 & 5 & 14 & 2 & 37 \\
\hline 14-apr-08 & 0 & 0 & 4 & 1 & 3 & 2 & 6 & 0 & 3 & 1 & 0 & 0 & 0 & 10 & 4 & 3 & 37 \\
\hline 16-mrt-09 & 1 & 6 & 0 & 2 & 2 & 1 & 11 & 0 & 3 & 0 & 6 & & 3 & 7 & 3 & 2 & 47 \\
\hline 24-mrt-09 & 0 & 6 & 0 & 6 & 2 & 9 & 5 & 4 & 6 & 5 & 4 & 0 & 0 & 3 & 1 & 7 & 58 \\
\hline 30-mrt-09 & 1 & 0 & 3 & 3 & 2 & 5 & 3 & 6 & 1 & 3 & 7 & 0 & 4 & 11 & 5 & 6 & 60 \\
\hline 07-apr-09 & 0 & 3 & 3 & 1 & 5 & 1 & 2 & 2 & 0 & 4 & 10 & 0 & 1 & 5 & 0 & 9 & 46 \\
\hline 22-mrt-10 & 9 & 3 & 0 & 1 & 2 & 1 & 3 & 0 & 3 & 6 & 0 & $\overline{0}$ & 0 & 5 & 2 & 0 & 35 \\
\hline 30-mrt-10 & 3 & 3 & 4 & 3 & 1 & 1 & 3 & 3 & 0 & 1 & 4 & 1 & 1 & 9 & 3 & 13 & 53 \\
\hline 12-apr-10 & 3 & 0 & 0 & 6 & 1 & 2 & 0 & 2 & 0 & 9 & 3 & 0 & 1 & 2 & 2 & 2 & 33 \\
\hline 20-apr-10 & 0 & 1 & 2 & 0 & 1 & 1 & 2 & 1 & 0 & 5 & 2 & 1 & 2 & 0 & 0 & 4 & 22 \\
\hline 21-mrt-11 & 0 & 2 & 0 & 3 & 8 & 0 & 1 & 0 & 0 & 4 & 3 & 0 & 2 & 1 & 0 & 2 & 26 \\
\hline 29-mrt-11 & 0 & 0 & 0 & 2 & 2 & 0 & 3 & 0 & 0 & 1 & 1 & 4 & 5 & 0 & 1 & 12 & 31 \\
\hline 04-apr-11 & 2 & 1 & 2 & 3 & 3 & 0 & 9 & 2 & 4 & 0 & 1 & 0 & 0 & 2 & 0 & 2 & 31 \\
\hline 12-apr-11 & 3 & 0 & 0 & 5 & 7 & 0 & 1 & 1 & 2 & 2 & 1 & 0 & 0 & 0 & 2 & 0 & 24 \\
\hline 19-mrt-12 & 3 & 0 & 0 & 3 & 3 & 0 & 2 & 2 & 0 & 2 & 2 & 0 & 1 & 1 & 5 & 0 & 24 \\
\hline 27-mrt-12 & 0 & 0 & 4 & 6 & 5 & 0 & 4 & 1 & 0 & 2 & 0 & 0 & 5 & 0 & 0 & 5 & 32 \\
\hline 02-apr-12 & 0 & 1 & 0 & 1 & 3 & 0 & 3 & 1 & 0 & 1 & 0 & 0 & 4 & 2 & 0 & 2 & 18 \\
\hline 10-apr-12 & 0 & 0 & 3 & 8 & 2 & 0 & 2 & 1 & 3 & 1 & 2 & 0 & 0 & 0 & 0 & 3 & 25 \\
\hline 18-mrt-13 & 0 & 0 & 0 & 4 & 10 & 0 & 3 & 0 & 0 & 3 & 0 & 2 & 0 & 4 & 0 & 1 & 27 \\
\hline $26-\mathrm{mrt}-13$ & 1 & 1 & 1 & 9 & 1 & 0 & 0 & 0 & 0 & 1 & 0 & 0 & 5 & 1 & 1 & 4 & 25 \\
\hline 08-apr-13 & 1 & 0 & 0 & 7 & 9 & 0 & 5 & 0 & 0 & 4 & 0 & 1 & 0 & 0 & 0 & 5 & 32 \\
\hline 16-apr-13 & 2 & 0 & 2 & 4 & 7 & 0 & 2 & 0 & 0 & 2 & 0 & 0 & 0 & 0 & 0 & 3 & 22 \\
\hline
\end{tabular}




\subsection{Kilometerindex (KI)}

In Figuur 3.1 wordt de spreiding van de gegevens uit de vier verschillende tellingen per jaar weergegeven. In 2006 bestond elk van die tellingen slechts uit vijf in plaats van 16 trajecten, wat de aanzienlijk grotere spreiding in dat jaar verklaart (variatiecoëfficiënt $\left.\left(c_{v}\right)=0,37\right)$. Verder is het enkel in 2010 dat de spreiding opnieuw aanzienlijk was $\left(c_{v}=\right.$ 0,36), als een gevolg van het hoge aantal reeën dat op 30 maart 2010 werd geteld. Voor de overige jaren blijft de spreiding tussen de minimale en maximale kilometerindex per telling in de overige jaren onder de 0,3 ree per kilometer $\left(c_{v}=0,10-0,25\right)$.

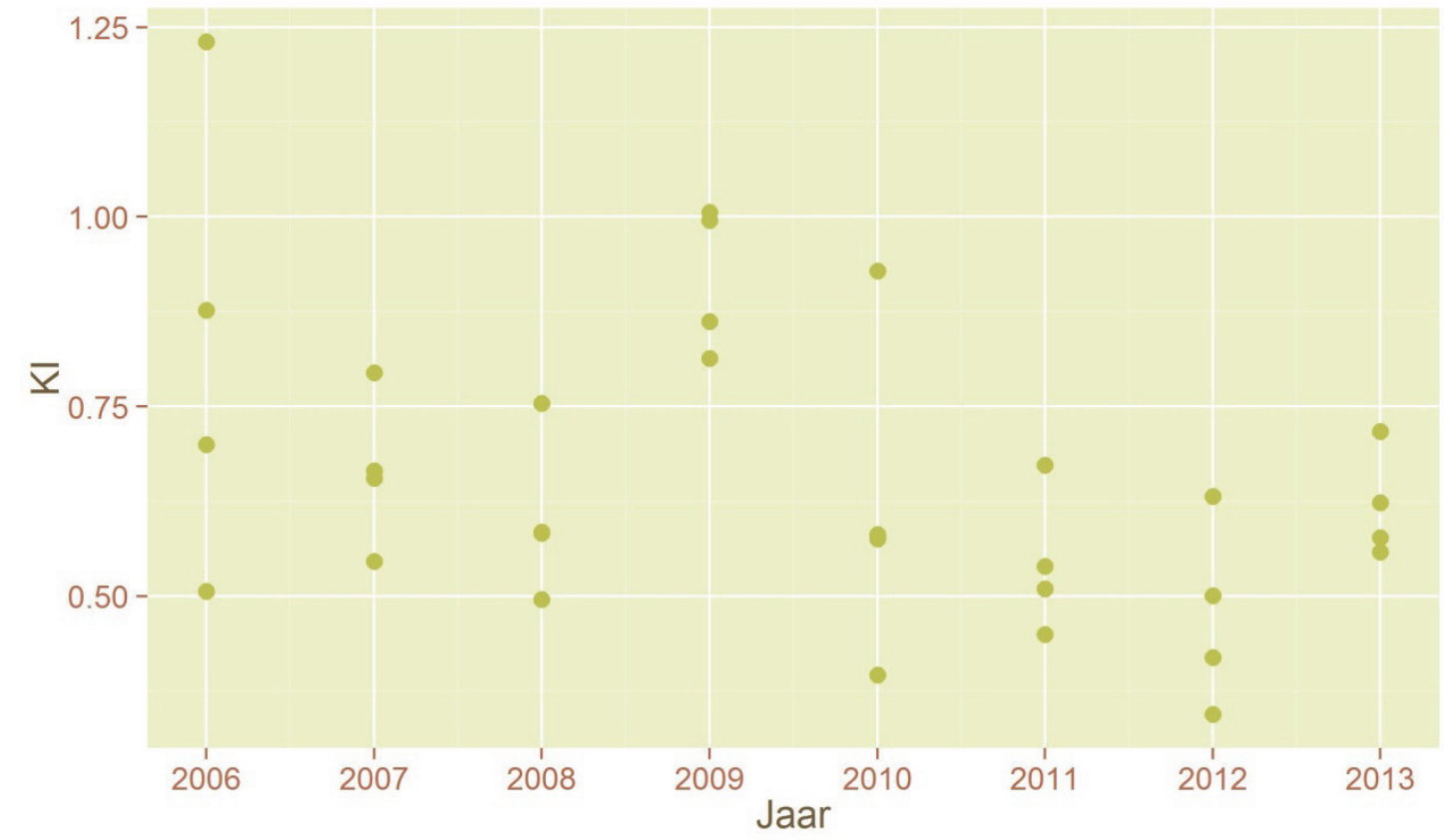

Figuur 3.1: Spreiding van de kilometerindexen per telling voor elk van de verschillende jaren.

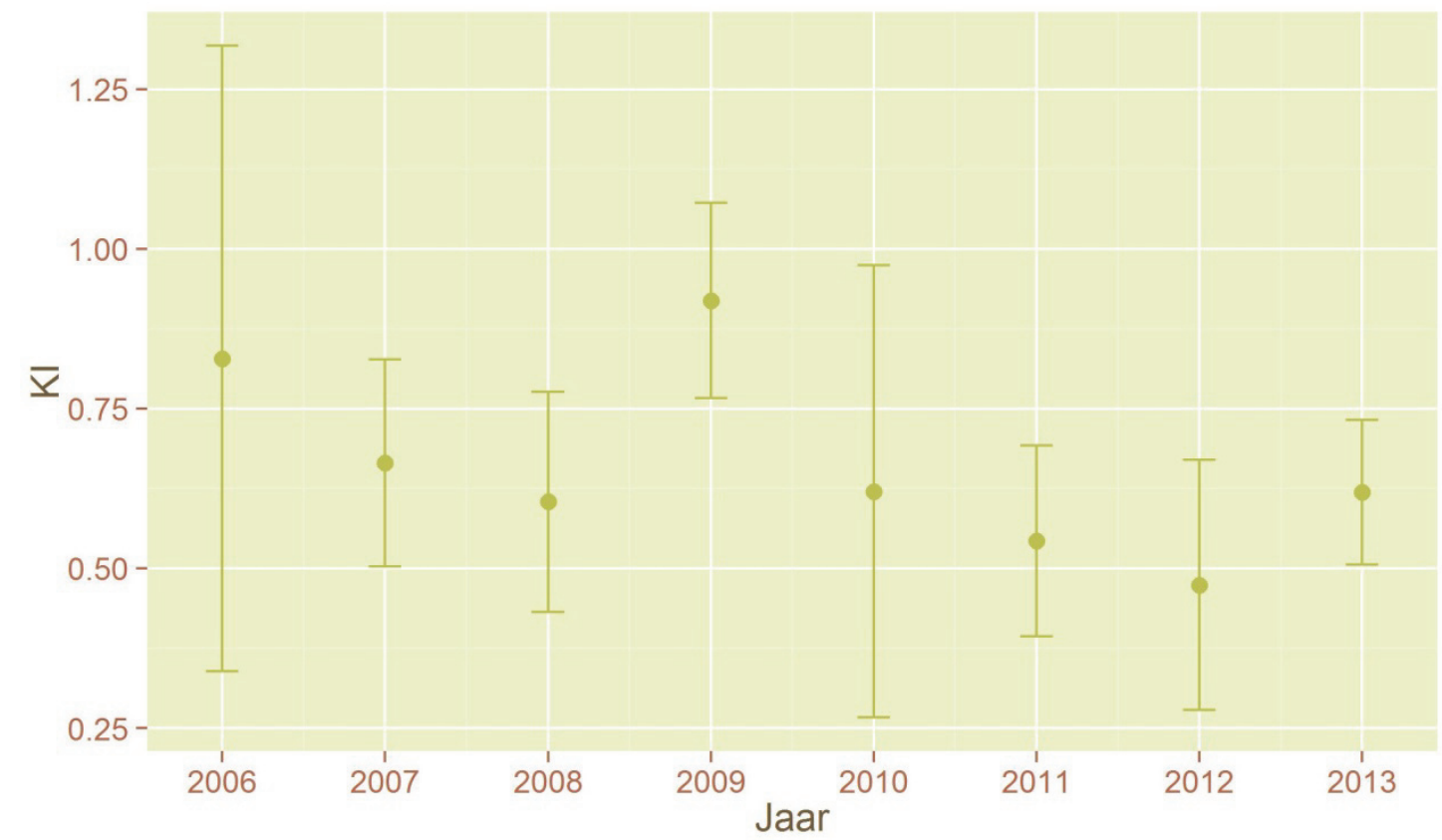

Figuur 3.2: Gemiddelde kilometerindex over alle trajecten per jaar (+/- 95\% betrouwbaarheidsinterval). 
In Figuur 3.2 wordt een overzicht gegeven van de gemiddelde kilometerindexen per jaar, met weergave van het $95 \%$ betrouwbaarheidsinterval. Daaruit blijkt dat, wanneer we abstractie maken van 2006 waarin minder trajecten werden geteld, de gemiddelde kilometerindex weinig is veranderd over de volledige periode. Waar in 2007 een gemiddelde KI van 0,67 werd opgetekend, was dit in 2013 nog steeds 0,62 met ruim overlappende betrouwbaarheidsintervallen tussen beide jaren. Verder liggen ook de gemiddelden voor 2008, 2010 en 2011 (respectievelijk 0,60, 0,62 en 0,54) allemaal binnen het bereik van de betrouwbaarheidsintervallen voor 2007 en 2013. Enkel in 2012 werd een lichtjes lager gemiddelde $(0,47)$ opgetekend. De enige aberrante waarde over de volledige telperiode is daarmee enkel die van 2009 waarin een gemiddelde KI van 0,92 werd opgetekend.

\subsubsection{Interactie met beheeringrepen}

Omwille van de intensieve beheerwerken die in het zuidelijke deel van de getelde boscomplexen (Averbode Bos en Heide en Gerhagen, in Figuur 3.3 kortweg 'Averbode') in het kader van het LIFE-project werden uitgevoerd is het interessant om ook eens na te gaan in welke mate die kilometerindexen afwijken van die uit de overheidsbossen in het noordelijk deel ('Overheid' in Figuur 3.3). Uit Figuur 3.3 blijkt wel degelijk een sterk verschil tussen beide gebieden te bestaan. Tot 2010 lopen de waarden voor beide deelgebieden zeer gelijk, maar vanaf 2011 wordt een duidelijke discrepantie zichtbaar. Daarbij daalt de KI voor het zuidelijke complex tot onder de 0,5 terwijl die voor het noordelijk deel aanvankelijk stabiel blijft en in 2013 zelfs toeneemt tot bijna 1. Daarbij valt op dat in 2013 ook de betrouwbaarheidsintervallen voor beide gemiddelden niet langer overlappen waardoor het verschil tussen beide waarden significant wordt.

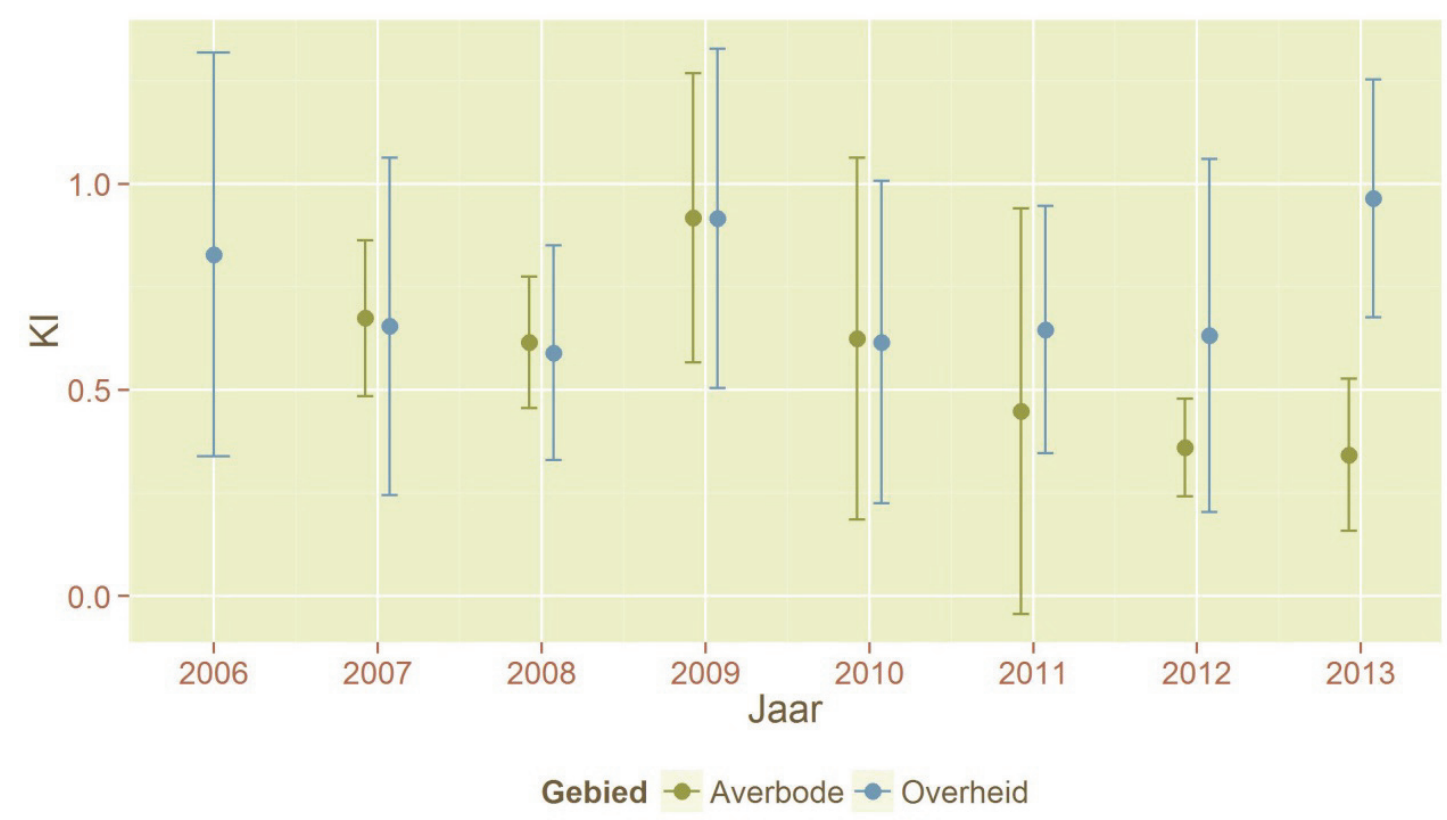

Figuur 3.3: Gemiddelde jaarlijkse kilometerindex per gebiedscluster. 


\subsubsection{Vergelijking met afschot en bio-indicatoren omliggende WBE's}

\subsubsection{Afschot}

Wanneer we de evolutie van het afschot per 100 ha bos van de omliggende WBE's gedurende de projectjaren bekijken zien we een sterk gedifferentieerd beeld (Figuur 3.4). Waar in de twee noordelijk gelegen WBE's Laakdal en Zuiderkempen het afschot vrijwel stabiel is gebleven of slechts licht is gedaald (tot respectievlijk 77 en $91 \%$ van het afschot in 2006), is het afschot in de andere twee WBE's (Demervallei en Tessenderlo) gedaald tot respectievelijk 53 en $16 \%$ van het afschot in 2006. Daarbij valt op dat vooral in de jaren 2010 en 2011 zich de grootste veranderingen voordoen.

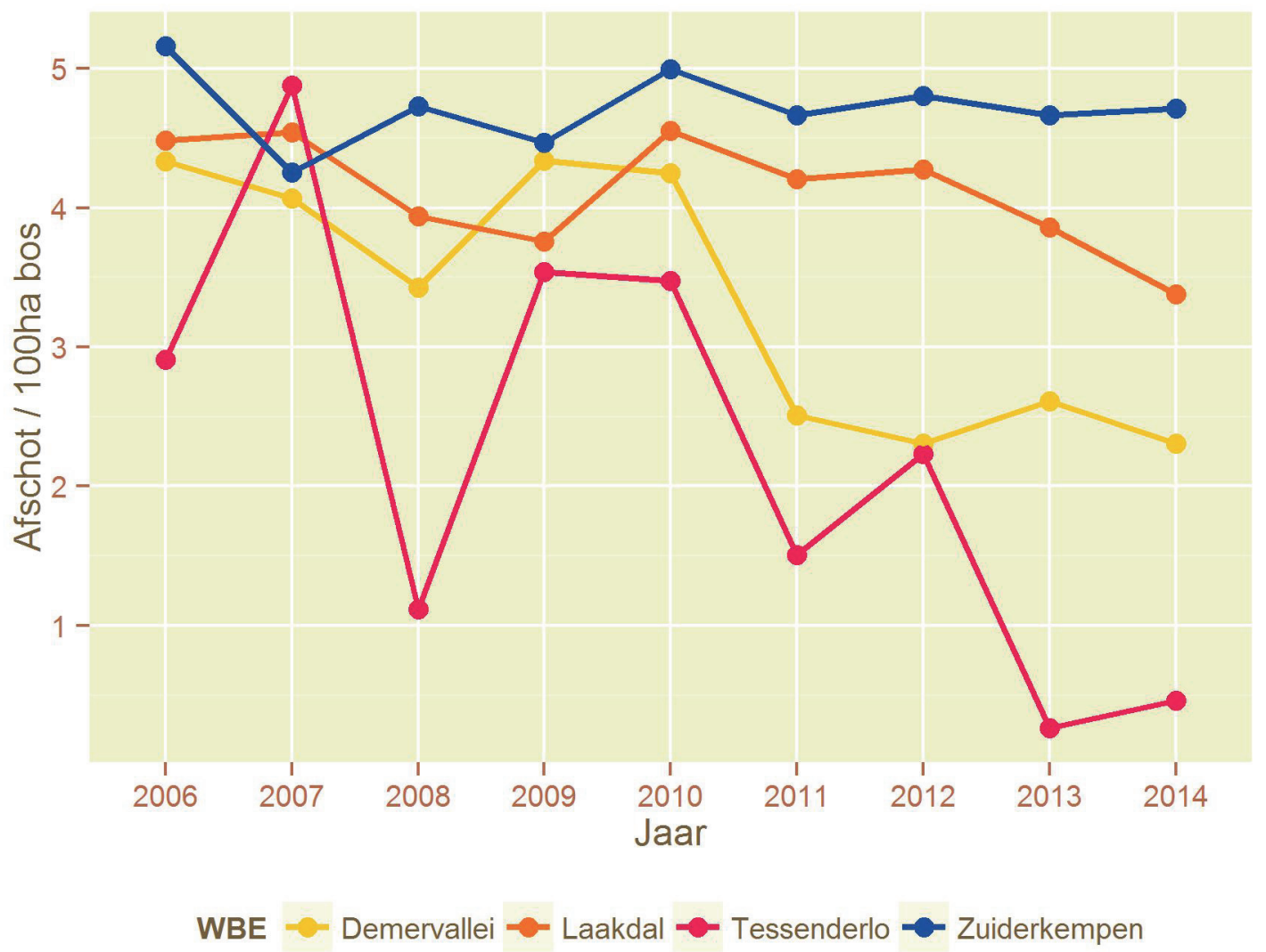

Figuur 3.4: Evolutie van het afschot van ree per 100 ha bos in de WBE's gelegen rondom het de Merodecomplex.

\subsubsection{Bio-indicatoren}

Bij een analyse van de gerapporteerde gegevens omtrent de verschillende bio-indicatoren zijn slechts beperkte veranderingen merkbaar over de projectperiode. Het gemiddeld kitsgewicht schommelt in elk van de geanalyseerde WBE's rond de $12 \mathrm{~kg}$ over de volledige periode, een waarde die perfect aansluit bij de gekende gemiddeldes voor gans Vlaanderen (zie Scheppers et al. 2013, 2014, Huysentruyt et al. 2015). Ook de onderkaaklengte blijft over de volledige periode vrij stabiel en in de WBE's Demervallei, Laakdal en Tessenderlo overstijgen de gemiddelde waarden rond de $145 \mathrm{~mm}$ in 2014 zelfs ruim de Vlaamse gemiddelden (zie Scheppers et al. 2013, 2014, Huysentruyt et al. 2015). Enkel in WBE Zuiderkempen ligt de waarde voor 2014 iets lager dan de voorgaande jaren maar wel nog steeds op het Vlaamse gemiddelde (zie Scheppers et al. 2013, 2014, Huysentruyt et al. 2015). 


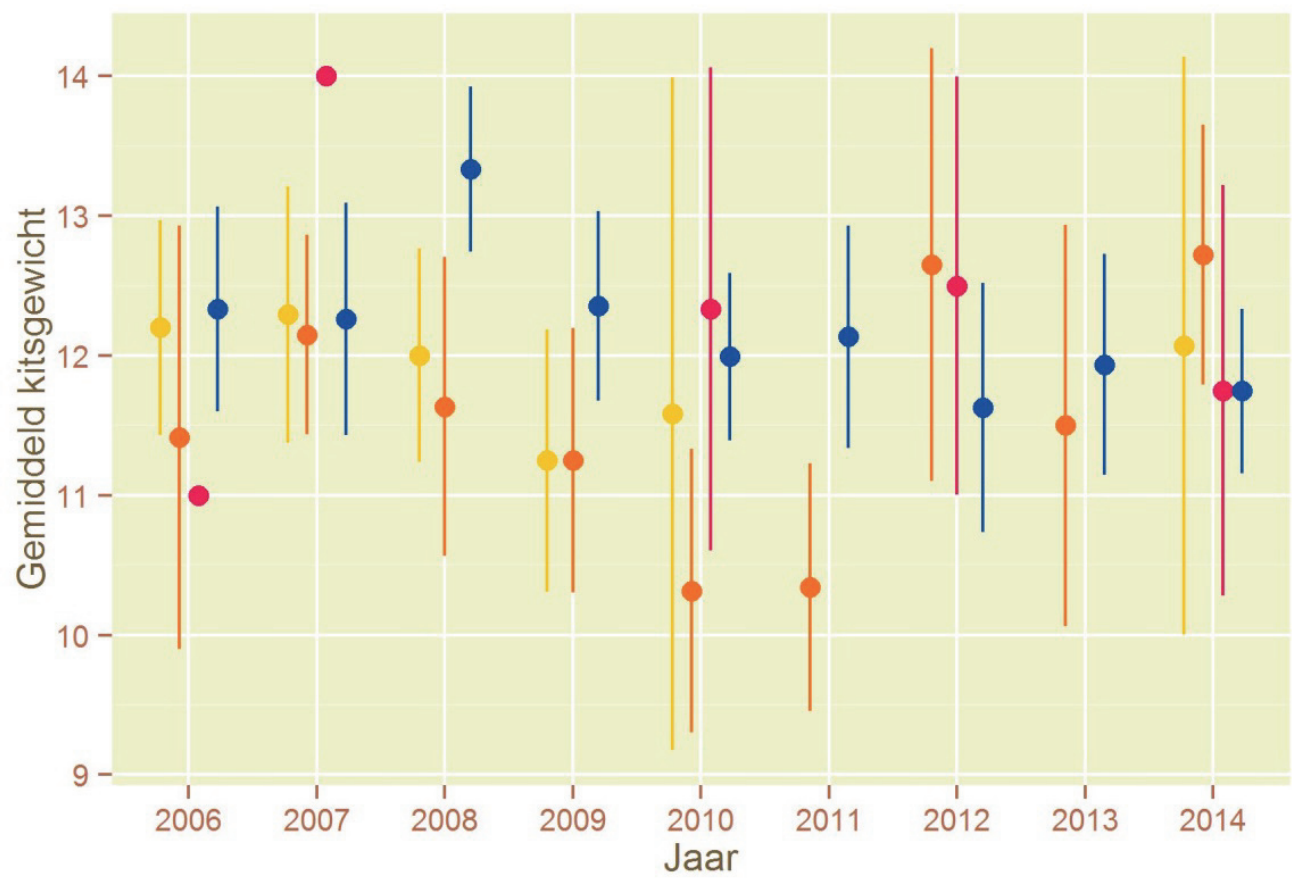

WBE - - Demervallei - Laakdal $\bullet-$ Tessenderlo $\bullet$ - Zuiderkempen

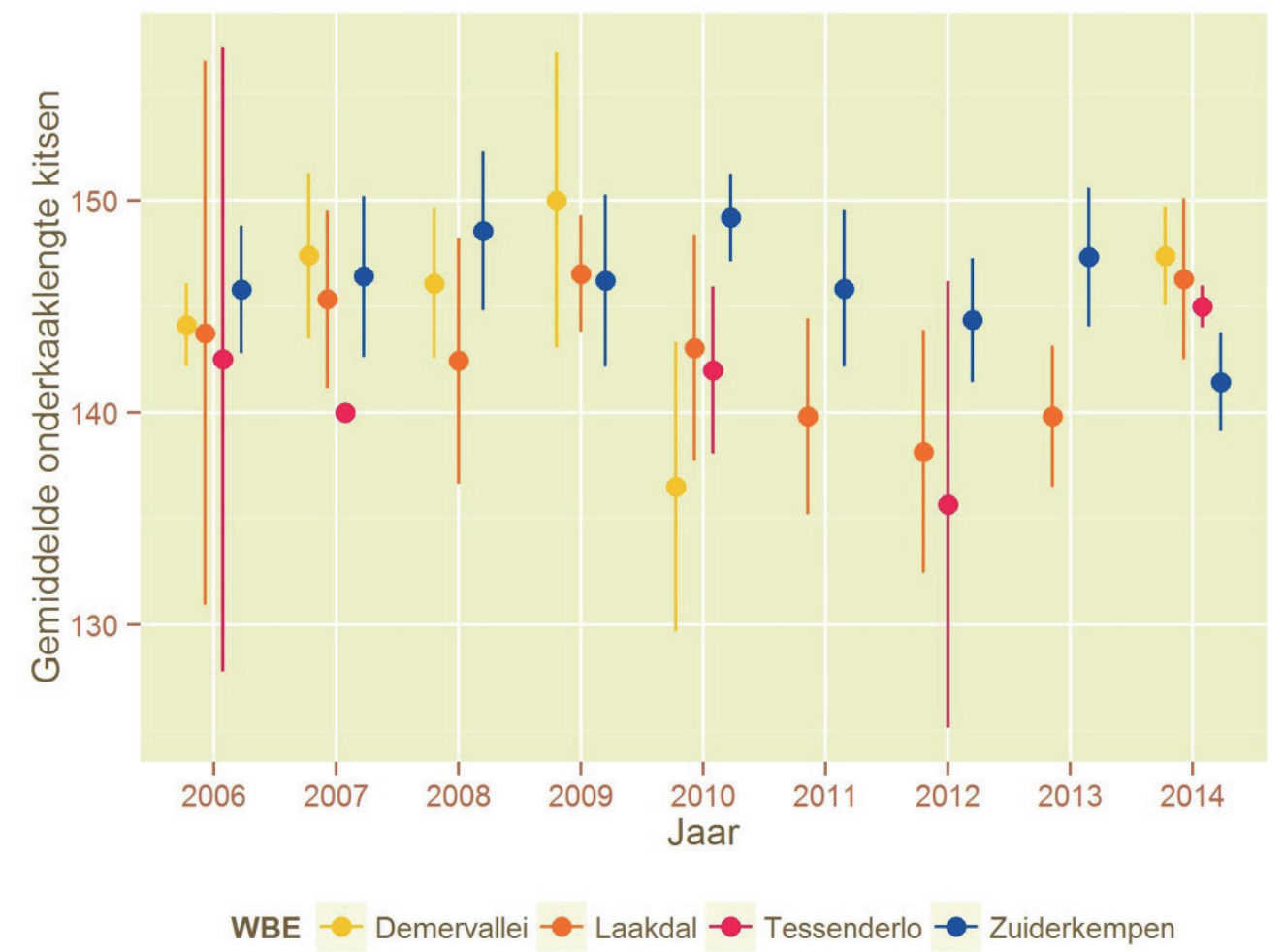

Figuur 3.5: Evolutie van het gerapporteerd leeggewicht en onderkaaklengte per WBE aangrenzend aan het Merodecomplex (gemiddelde $+/$ - $95 \%$ betrouwbaarheidsinterval). 
De bio-indicatoren die betrekking hebben op de voortplanting vertonen meer variatie dan de indicatoren die de lichaamsconditie bij de kitsen beschrijven. In alle gevallen, hoewel vaak uit vrij beperkte stalen, neemt het aandeel niet-zwangere dieren over de ganse periode licht toe (Figuur 3.6). In drie van de vier WBE's neemt daarbij ook het gemiddeld aantal embryo's per zwanger dier licht af, van 1,7-1,9 bij aanvang tot ongeveer 1,5 bij het einde van het project. Hierbij liggen de waarden lager dan de 1,7 die gemiddeld voor Vlaanderen wordt gerapporteerd (Scheppers et al. 2013, 2014, Huysentruyt et al. 2015). Voor WBE Tessenderlo ligt de waarde in 2014 en in enkele voorgaande jaren aanzienlijk hoger, maar door de zeer lage aantallen geschoten reeën over alle jaren is een exacte interpretatie hiervan niet echt zinvol.
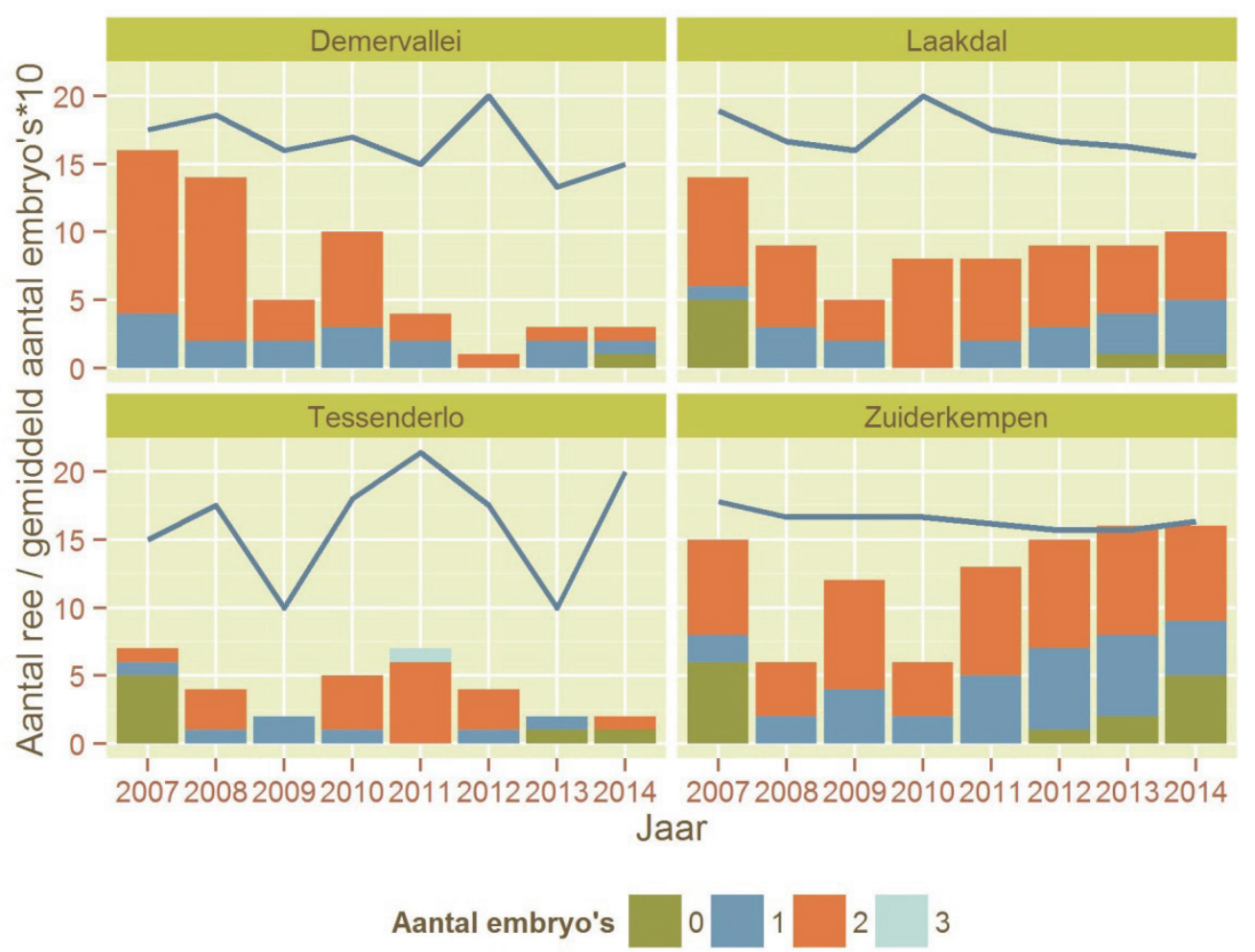

Figuur 3.6: Aantal vrouwelijke reeën met 0, 1, 2 of 3 embryo's (balken) en het gemiddeld aantal embryo's per drachtig ree (x10, lijn). 
Uit de gegevens over het volledige de Merodecomplex lijkt de populatie over alle jaren heen stabiel gebleven te zijn rond ongeveer 0,6 geobserveerde reeën per kilometer afgelegd traject. Deze vaststelling past binnen de algemene vaststelling dat het afschot van reeën in de drie provincies waarbinnen het boscomplex is gelegen (Antwerpen, Limburg en Vlaams-Brabant) al sinds 2010 een afvlakking vertoont, wat er op wijst dat de reepopulatie in het oostelijk deel van Vlaanderen vermoedelijk zijn draagvlak stilaan heeft bereikt (Scheppers et al. 2013).

Toch blijkt dat de situatie in het hier geëvalueerde complex iets genuanceerder is, wanneer het noordelijk deelgebied de Merode, afzonderlijk van de zuidelijker gelegen deelgebieden Gerhagen en Averbode Bos en Heide wordt geëvalueerd. In dit meer zuidelijk deel werd in het kader van heideherstel binnen een LIFE-project $20 \%$ van het dennenbos gekapt en geplagd in de periode 2007-2009 (Natuurpunt 2012). We zien dat daaropvolgend, vanaf 2010, de kilometerindexen voor ree in dit deel sterk dalen. In 2010 is die daling aanvankelijk ook merkbaar in het noordelijk deel, maar vanaf 2011 beginnen beide waarden uit beide delen in toenemende mate van elkaar te verschillen. De kilometerindexen in het zuiden blijven verder dalen, terwijl de waarden toenemen in het noorden en in 2014 zelfs sterk. Het lijkt logisch te veronderstellen dat deze verschillen een gevolg zijn van het uitgevoerde heideherstel. Bij de interpretatie van deze twee trends moet daarenboven ook rekening worden gehouden met het effect van de veranderingen in het habitat op de waarnemingskans. In het zuidelijke deel waar de omvorming naar een meer open gebied uitgevoerd werd, neemt de waarnemingskans immers toe. In de andere gebieden werden lokaal ook wel kappingen uitgevoerd maar nam op andere plaatsen de waarnemingskans af door het toegroeien van bestanden. We gaan er dus van uit dat voor die gebieden de waarnemingskans stabiel bleef of misschien zelfs afnam. Wanneer we deze elementen combineren met de resultaten van de tellingen wil dit zeggen dat werkelijke verschillen in trends tussen de gebieden nog sterker kunnen zijn dan de geobserveerde. Tot slot zou de geobserveerde afname in het zuidelijke, meer open, gebied en de toename in de overige gebieden ook deels het gevolg kunnen zijn van een verschuiving in het habitatgebruik van de reeënpopulatie binnen het volledige gebied.

De vaststelling dat er door de ingrepen in het habitat minder reeën in het zuidelijk deel waargenomen worden terwijl de populatie in het noordelijk deel blijkt toe te nemen wordt bevestigd door de afschotgegevens uit de omliggende WBE's. De voornaamste vaststelling is dat het afschot in de twee WBE's die aan het zuidelijk complex Averbode Bos en Heide en Gerhagen grenzen zeer sterk is afgenomen, terwijl dat in de WBE's die voornamelijk aan het deelgebied de Merode grenzen veel minder het geval was. Een deel van de verklaring hiervoor kan zijn dat reeën zich, na de beheerwerken, van het zuidelijk deel naar het noordelijk deel hebben verplaatst. Daarbij bleven de bio-indicatoren in alle WBE's wel op niveau en vergelijkbaar met de gemiddelde waarden voor Vlaanderen, al nam de reproductie in het noordelijk deel in de laatste jaren licht af. Ook dit wijst erop dat de populatie in het noordelijk deel, net als in de brede omliggende regio, in de laatste jaren het draagvlak aan het benaderen is. De bioindicatoren in WBE's Tessenderlo en Demervallei zijn door de veel lagere aantallen in de laatste jaren moeilijker te interpreteren.

Samenvattend kan worden gesteld dat de populatie in het volledige complex stabiel is gebleven en niet de toename heeft gekend die verwacht kan worden na het beëindigen van de jachtactiviteiten in een gebied.

Wel hebben zich, mogelijks als gevolg van uitgevoerde beheerwerken in het zuidelijk deel van het gebied, vermoedelijk verschuivingen in de ruimtelijke verspreiding van ree in het volledige complex voorgedaan. Zowel de telgegevens als de afschotcijfers van de omliggende WBE's, en in mindere mate de bio-indicatoren van het geschoten reewild, geven aan dat de populatie zich deels van het zuidelijk deel van het complex naar het noordelijk deel heeft verplaatst. Het feit dat alle omliggende WBE's een daling van het afschot kenden en dat in het noordelijk deel van het complex de populatie verder toenam, kan er ook op wijzen dat reeën, zoals wel werd verwacht, zich deels ook van de bejaagde naar de niet-bejaagde zones hebben verplaatst, al is dit effect, door het effect van de uitgevoerde beheerwerken op de verspreiding, niet eenduidig vast te stellen. 


\section{Referenties}

Ballon P. 1999. Indicateurs de la relation population-environnement pour le suivi des populations de chevreuils de plaine. Bulletin mensuel de l'Office national de la Chasse, 244:22-29.

Blant M \& Gaillard JM. 2004. Use of biometric body variables as indicators of roe deer (Capreolus capreolus) population density changes. Game and Wildlife Science, 21:21-40.

Casaer J. 2003. Analysing roe deer habitat selection; methodological problems and possible solutions. K.U.Leuven. Dissertationes de agricultura (nr : 550). 195 pp.

Casaer J \& Malengreaux C. 2008. Studie ter voorbereiding van het monitoren van de reewildpopulatiegrootte in Zoniën. Instituut voor Natuur- en Bosonderzoek, Brussel. 40 pp.

Cederlund G, Bergqvist J, Kjellander P, Gill R, Gaillard JM, Boisaubert B, Ballon P \& Duncan P. 1998. Managing roe deer and their impact on the environment: maximizing the net benefits to society. In: Andersen R, Duncan P \& Linnell JDC (eds.). The European roe deer: the biology of success. Scandinavian University Press, p. 337-372.

Delorme D. 1989. L'effet observateur : une source de biais lors de l'application de l'indice kilométrique d'abondance (I.K.A.) pour le dénombrement de chevreuils (Capreolus capreolus). Gibier Faune Sauvage, 6:309-314.

Delorme D. 2003. Gestion moderne du Chevreuil : de la validation à l'application des bioindicateurs. Forêt wallonne, 63:39-44.

Ellenberg H. 1974. Beobachtbarkeit und Zählbarkeirt von Rehen. BJV - Mitteilungen “Jagd in Bayern”, juni 1974.

Gaillaird JM. 1988. Contribution a la dynamique des populations de grands mammiferes: l'exemple du chevreuil (Capreolus capreolus). These présentée pour l'obtention du diplome de doctorat. Université Claude-Bernard, Lyon. $320 \mathrm{pp}$.

Gaillard JM, Sempéré AJ, Boutin JM, Laere GV \& Boisaubert B. 1992. Effects of age and body weight on the proportion of females breeding in a population of roe deer (Capreolus capreolus). Canadian Journal of Zoology, 70:1541-1545.

Groupe Chevreuil. 1991. Méthodes de suivi des populations de chevreuils en forêt de plaine: exemple : I'Indice Kilométrique (I.K.). Supplément au Bulletin Mensuel de l'Office National de la Chasse, 157, Fiche n70. 4 pp.

Hanks J. 1981. Characterization of population condition. In: Fowler CW \& Smiths TD (eds.). Dynamics of large mammal populations. Wiley, New York, p. 47-73.

Hewison AJM, Gaillard JM, Angibault JM, Van Laere G \& Vincent JP. 2002. The influence of density on post-weaning growth in roe deer Capreolus capreolus fawns. Journal of Zoology, 257:303-309.

Huysentruyt F \& Casaer J. 2012. Driejarenafschotplan voor reewild: het gebruik van bio-indicatoren en jachtgegevens voor de toekenning van het afschot bij ree. Instituut voor Natuur- en Bosonderzoek, Brussel. 68 pp.

Huysentruyt F, Scheppers T, Neukermans A, Vercammen J, Verschaffel E \& Casaer J. 2015. Grofwildjacht in Vlaanderen: cijfers en statistieken 2014. Instituut voor Natuur- en Bosonderzoek, Brussel. 40 pp.

Kjellander P. 2000. Density dependence in roe deer population dynamics. Doctoral thesis, Swedish University of Agricultural Sciences, Uppsala. $127 \mathrm{pp}$.

Kjellander P, Gaillard JM \& Hewison AJM. 2006. Density-dependent responses of fawn cohort body mass in two contrasting roe deer populations. Oecologia, 146:521-530.

Natuurpunt. 2012. LIFE Averbode Bos \& Heide. Natuurherstel in een landschap vol geschiedenis. Natuurpunt vzw, Mechelen. 12 pp.

ONC (Office National de la Chasse) 1996. Fiche technique $n^{\circ} 90$. Les bio-indicateurs: futurs outils de gestion des populations de chevreuils? Supplément au bulletin mensuel de l'office national de la chasse $n^{\circ} 209$. 
ONC (Office National de la Chasse) 1999. Fiche technique $n^{\circ} 95$. La gestion des populations de chevreuils par I'utilisation d'indicateurs population-environnement. Supplément au bulletin mensuel de l'office national de la chasse $n^{\circ} 244$.

ONCFS (Office National de la Chasse et de la Fauna Sauvage) 2015. Fiches techniques $\mathrm{n}^{\circ} 1$. Indice Kilométrique Pédestre (IKP).

Petorelli N, Gaillaird JM, Duncan P, Ouellet JP \& Van Laere G. 2001. Population density and small-scale variation in habitat quality affect phenotypic quality in roe deer. Oecologia, 128:400-405.

Scheppers T, Huysentruyt F, Neukermans A, Vercammen J, Verschaffel E \& Casaer J. 2013. Grofwildjacht in Vlaanderen: cijfers en statistieken over de periode 2002 - 2012. Rapporten van het Instituut voor Natuur- en Bosonderzoek, Instituut voor Natuur- en Bosonderzoek, Brussel. 94 pp.

Scheppers T, Huysentruyt F, Neukermans A, Vercammen J, Verschaffel E \& Casaer J. 2014. Grofwildjacht in Vlaanderen: cijfers en statistieken 2013. Mededelingen van het Instituut voor Natuur- en Bosonderzoek, Instituut voor Natuur- en Bosonderzoek, Brussel. 40 pp.

Toïgo C, Gaillard JM, Van Laere G, Hewison M \& Morellet N. 2006. How does environmental variation influence body mass, body size, and body condition? Roe deer as a case study. Ecography, 29:301-308.

Vincent JP \& Bideau E. 1982. Note About the Visibility Index Determination - Utilization for Roe Deer Census. Acta Oecologica-Oecologia Applicata, 3:257-262.

Vincent JP \& Bideau E. 1992. Conséquences d'une modification importante de la densité sur une population de chevreuils forestiers. Bulletin mensuel de l'office national de la chasse, 162:30-33.

Vincent JP, Gaillard JM \& Bideau E. 1991. Kilometric index as biological indicator for monitoring forest roe deer populations. Acta Theriologica, 36:315-328.

Vincent JP, Bideau E, Hewison AJM \& Angibault JM. 1995. The Influence of Increasing Density on Body-Weight, Kid Production, Home-Range and Winter Grouping in Roe Deer (Capreolus capreolus). Journal of Zoology, 236:371-382.

Vincent JP, Hewison AJM, Angibault JM \& Cargnelutti B. 1996. Testing density estimators on a fallow deer population of known size. Journal of Wildlife Management, 60:18-28.

Werkgroep Ecologie Tessenderlo. 2015. http://wet.gerhagen.be/gerhagen/natuurgebied-gerhagen. 


\section{Bijlage 1: formulier reewildtelling}

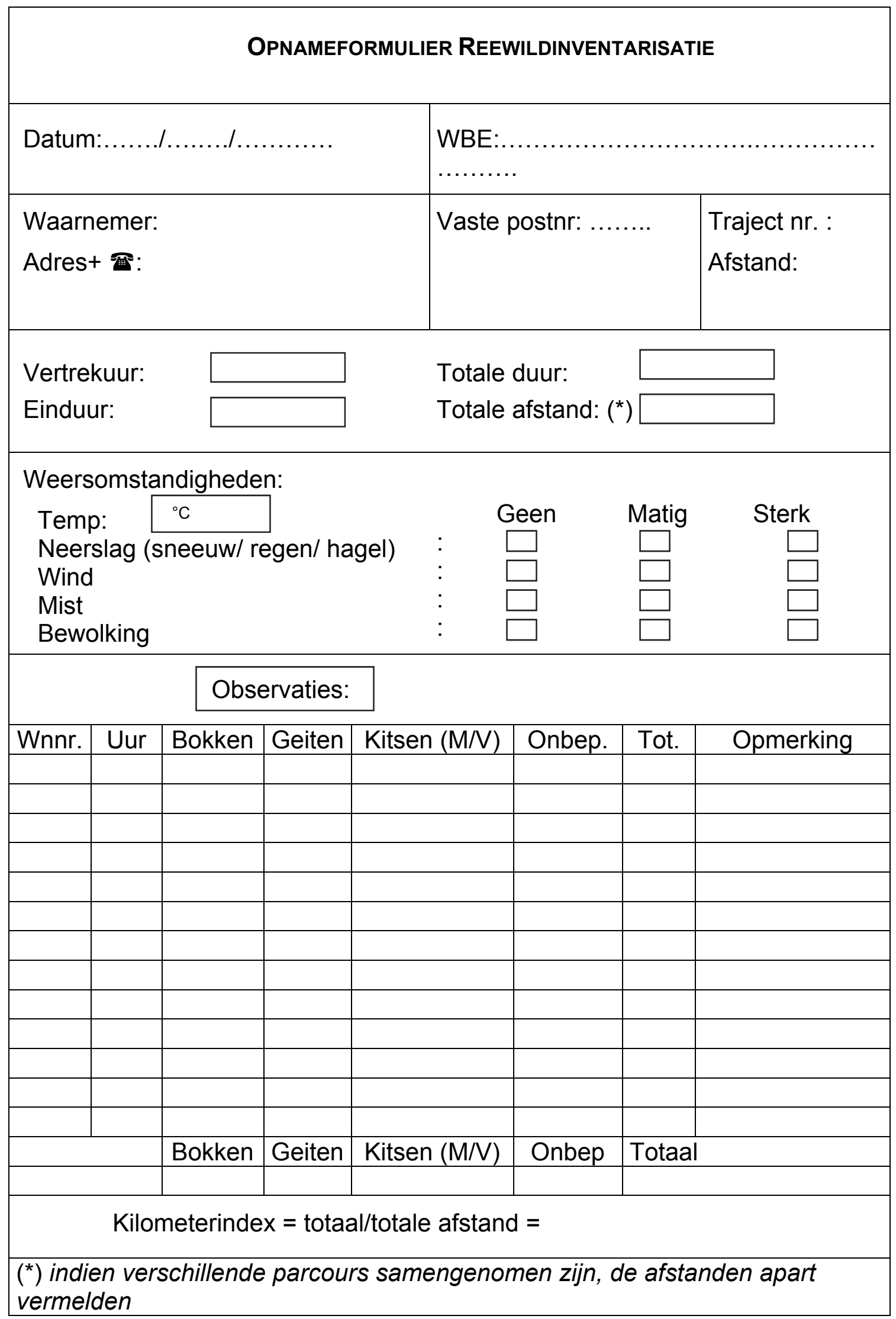


